Q1.523

c7 7547

1920
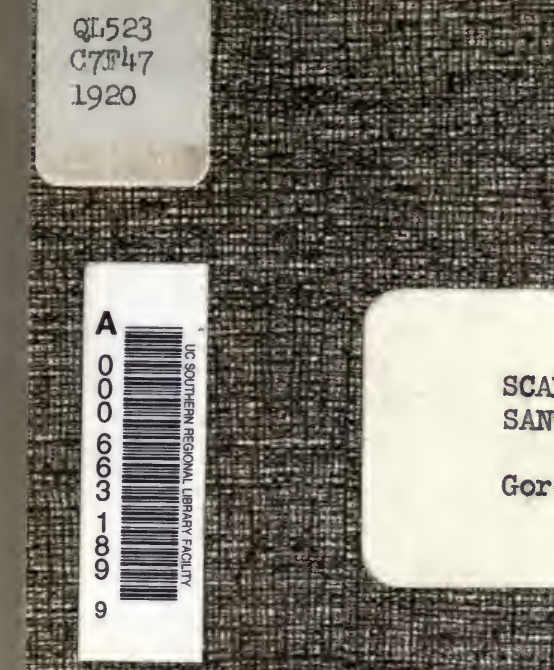

SCALE INSECTS OF THE

SANTA CRUZ PENINSULA

Gordon Floyd Ferris

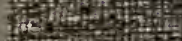

gifor
galifornia
gional
cility

gifor
galifornia
gional
cility

gifor
galifornia
gional
cility
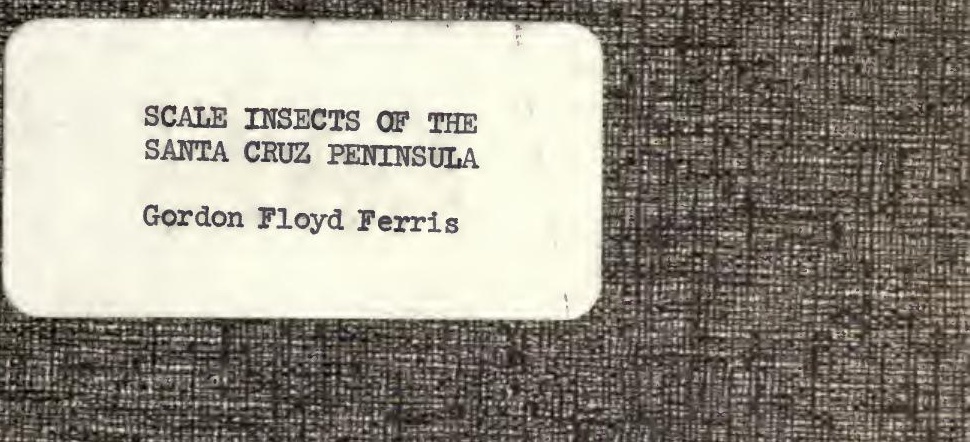

10.0 2 :

difing:

(1)

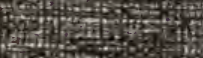

sind

(1)

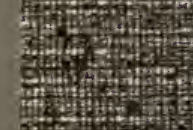

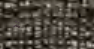

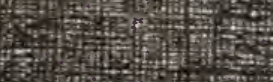

ing

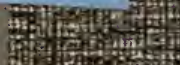
rof 
BIO-AGRICULTURAL LIBRARY

UNIVERSITY OF CALIFORNIA

RIVERSIDE, CALIFORNIA 92502 


\section{STANFORD UNIVERSITY PUBLICATIONS}

UNIVERSITY SERIES

B I O L O G I A L SCIENCES VoluMe I NUMBER 1

Scale Insects of the Santa Cruz Peninsula

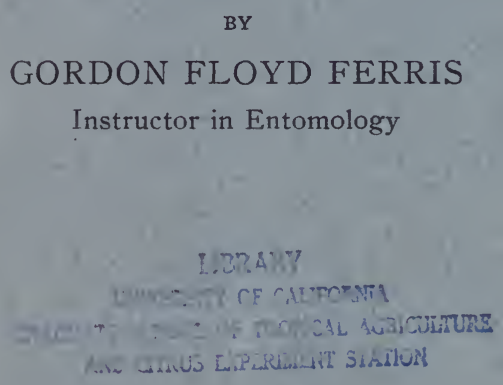

STANFORD UNIVERSITY, CALIFORNIA PUBLISHED BY THE UNIVERSITY 

STANFORD UNIVERSITY PUBLICATIONS UNIVERSITY SERIES

B I OLOGICAL SCIENCES Volume I

NuMBER 1

\title{
Scale Insects of the Santa Cruz Peninsula
}

\author{
BY \\ GORDON FLOYD FERRIS \\ Instructor in Entomology \\ LIBRARY \\ UNIVERSITY OF CALIFORNA \\ GRALUATE STHOOL OF TROPICAL AGRICULTURE \\ AID CITRUS EXPERIMLNT STATION
}
STANFORD UNIVERSITY, CALIFORNIA
PUBLISHED BY THE UNIVERSITY
1920


Stanford UNIVERsity Press 


\section{CONTENTS}

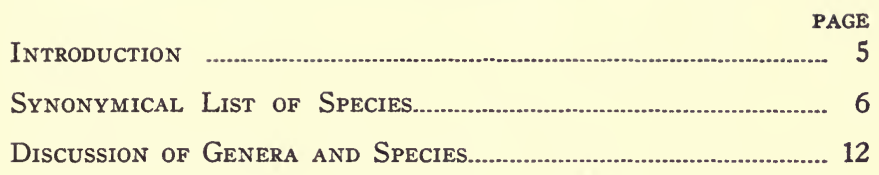




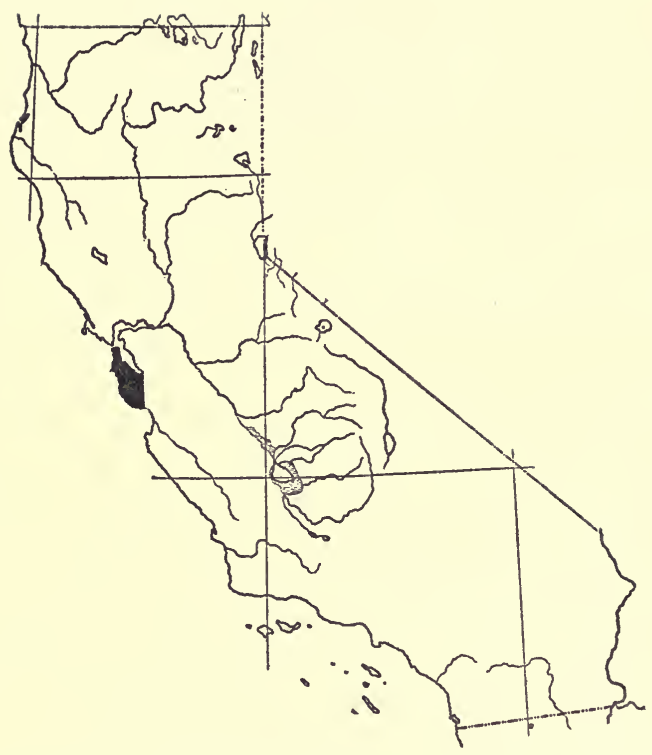

Fig. 1.-Sketch Map of California; the black area is the Santa Cruz Peninsula. 


\section{INTRODUCTION}

It is probable that the scale-insect fauna of no area of comparable extent, unless it be that of the region surrounding the Mesilla Valley in New Mexico, is better known than is that of the Santa Cruz Peninsula in California. Nor is it probable that there are many areas of similar extent in which this group of insects is represented by a larger or more diversified list of species. Small as this peninsula is, more species are now known to occur out of doors within it than have been recorded in any of the various state lists that have been published (deducting synonyms), and it should be borne in mind that in all these lists there are included numerous species known only from their occurrence in greenhouses.

This richness of the Coccid fauna of the Santa Cruz Peninsula is due in part to the fact that many introduced species which are found only in greenhouses throughout much of the United States are here able to thrive out of doors. Nevertheless, of the ninety-two species recorded in this paper sixty are presumably native. The extent of our knowledge of these species is due to the efforts of a long series of students who for twenty years or more have been adding to it. A total of forty-six species, of which seven are now regarded as synonyms, have their type locality within this area.

The accompanying sketch map (Fig. 1) will give some idea of the size of this peninsula as compared with the entire state of California. For the purposes of this paper the Santa Cruz Peninsula is regarded as bounded on the south by a line drawn from Santa Cruz to San Jose and thence to the southern extremity of San Francisco Bay.

The presentation of a local list is but a small part of the real purpose of this paper. In the case of many of the included species the existing descriptions are in need of amplification, and in the case of many more the available figures (if, indeed, there be any) are inadequate. The opportunity has therefore been taken especially to present figures of numerous species. There is also included a considerable amount of information having to do with locality and host records and synonymy, together with discussions of certain matters of more general interest.

There are recorded in this list only species occurring out of doors. Were greenhouse species likewise to be considered, the list might be extended almost indefinitely.

The types of all new species herein described are in the Stanford University collection of Coccidæ. 


\section{SYNONंYMICAL LIST OF SPECIES}

Note.-Names in italics are synonyms. Only those names are included that have been used in referring to these species as they occur in California and the synonymy has not been carried back of the Fernald Catalogue. Species of which the type locality is on the Santa Cruz Peninsula are indicated by an asterisk.

purchasi Maskell.

Genus ICERYA Sign.

Genus XYLOCOCCUS Loew.

*quercus Ehrh.

Genus STOMACOCCUS Ferris.

*platani Ferris.

Genus ORTHEZIA Bosc.

*californica Ehrh. occidentalis Douglas.

occidentalis Douglas.

*californica Ehrh.

Genus ASTEROLECANIUM Targ.

variolosum (Ratz.)

Genus MYCETOCOCCUS Ferris.

*ehrhorni (Ckll.).

*Cerococcus ehrhorni Ck11.

*ehrhorni Ckll.

Genus CEROCOCCUS Comst.

*Mycetococcus ehrhorni (Ckll.).

Genus EHRHORNIA Ferris.

cupressi (Ehrh.).

Sphaerococcus cupressi Ehrh.

graminis Ferris

cupressi Ehrh.

Genus SPHÆROCOCCUS Maskell.

Ehrhornia cupressi (Ehrh.).

*disticlium Kuwana.

*Paludicoccus disticlium (Kuwana).

*disticlium (Kuwana).

Genus PALUDICOCCUS Ferris.

*Sphaerococcus disticlium Kuwana. 
*adenostomae Ehrh.

Genus ERIOCOCCUS Targ. araucariae Maskell.

*artemisiae Kuwana.

Erium lichtensioides (Ckll.).

*bahiae Ehrh.

catalinae Ehrh.

Erium lichtensioides (Ckl1.).

paenulatus $\mathrm{n}$. sp.

quercus (Comst.).

salinus Ehrh.

Cryptoripersia arizonensis (Ehrh.).

*stanfordianus n. sp.

*villosus n. sp.

\section{Genus GOSSYPARIA Sign.}

spuria (Modeer).

Genus KERMES Boit.

*cockerelli Ehrh.

essigii King.

nigropunctatus Ehrh.

nigropunctatus Ehrh.

essigii King.

*mirabilis King.

*rattani Ehrh.

*rattani Ehrh.

*mirabilis King.

Genus PHENACOCCUS Ckll.

*artemisiae Ehrh.

*bahiae Ehrh.

Puto yuccae (Coq.).

*colemani Ehrh.

*eriogoni Ferris.

*solani Ferris.

*stachyos Ehrh.

\section{Genus CEROPUTO Sulc.}

With all included species a synonym of Puto.

*ambigua (Full.).

\section{Genus PUTO Sign.}

*Ceroputo ambigua Full.

cupressi (Coleman).

Pseudococcus cupressi Coleman.

*Psendococcus sequoiae Coleman (as to male).

yuccae (Coq.).

*Phenacoccus bahiae Ehrh.

*Ceroputo bahiae (Ehrh.). 


\section{Genus PSEUDOCOCCUS Westwood.}

andersoni Coleman.

ryani (Coq.).

artemisiae Essig.

Erium lichtensioides (Ckll.).

aurilanatus (Maskell).

bakeri Essig.

*maritimus Ehrh.

sitrophilus Clausen.

gahani Green.

crawii (Coq.).

*quercus Ehrh. (in part).

*eriogoni Ehrh.

*Erium eriogoni (Ehrh.).

Pseudococcus yerba-santae Essig.

gahani Green

citrophilus Clausen.

*longisetosus Ferris.

*maritimus Ehrh.

bakeri Essig.

obscurus Essig.

obscurus Essig.

*maritimus Ehrh.

*quercicolus Ferris.

*quercus (Ehrh.) (in part).

*quercus Ehrh. (in part).

*quercicolus Ferris.

*quercus Ehrh. (in part). crawii (Coq.).

ryani (Coq.).

andersoni (Coleman).

sequoiae (Coleman) (as to female).

sequoiae (Coleman) (as to male).

Puto cupressi (Coleman).

salinus Ckll.

smithii (Essig.) (in part).

Trionymus californicus Ehrh.

*timberlakei Ckll.

yerba-santae Essig.

eriogoni (Ehrh.).

\section{Genus ERIUM Ckll.}

*eriogoni (Ehrh.).

Pseudococcus eriogoni (Ehrh.).

lichtensioides (Ckll.)

*Eriococcus artemisiae Kuwana.

Eriococcus catalinae Ehrh.

Pseudococcus artemisiae Essig. 


\section{Genus TRIONYMUS Berg.}

*bromi Ferris.

californicus Ehrh.

Ripersia smithii Essig (in part).

Pseudococcus smithii (Essig) (in part).

*distichlii Ferris.

* festucæ (Kuwana).

*Ripersia festucae Kuwana.

smithii (Essig) (in part).

Ripersia smithii Essig (in part).

Pseudococcus smithii (Essig) (in part)

villosa (Ehrh.).

Ripersia villosa Ehrh.

\section{Genus RIPERSIA Sign.}

*festucae Kuwana.

*Trionymus festucae (Kuwana).

smithii Essig (in part).

Trionymus smithii (Essig).

smithii Essig (in part).

Trionymus californicus Ehrh.

villosa Ehrh.

Trionymus villosus (Ehrh.).

Genus RIPERSIELLA Towns.

*kelloggi Ehrh.

\section{Genus CRYPTORIPERSIA Ckll.}

arizonensis (Ehrh.).

Eriococcus salinus Ehrh.

Cryptoripcrsia salinus (Ehrh.)

*californica (Ehrh.).

Genus ACLERDA Sign.

tokionis (Ckll.).

Genus PULVINARIA Targ.

*ehrhorni King.

*rhois Ehrh.

vitis (Linn.).

Genus COCCUS Linn.

cirricola Campbell.

hesperidum Linn.

Genus TOUMEYELLA Ckll.

*pinicola n. sp. 
*adenostomae Kuwana.

Genus LEĆANIUM III. corni (Bouché).

cerasorum Ckll. corni (Bouché).

*adenostomae Kuwana.

* crawii Ehrh.

*crawii Ehrh. corni (Bouché)

*excrescens $\mathrm{n}$. sp.

*magnoliarum Ckll. persicae Fab.

persicae Fab.

*magnoliarum Ckll.

pruinosum Coq.

*pubescens Ehrh.

nigra (Nietn.).

Genus SAISSETIA Dep.

oleae (Bern.).

Genus PHYSOKERMES Targ.

*insignicola (Craw).

*taxifoliae Coleman.

Genus CHIONASPIS Sign.

quercus Comst.

pinifoliae (Fitch).

spartinae Comst.

carueli Targ.

Genus DIASPIS Costa.

manzanitae (Whitney).

echinocacti (Bouché).

piricola (Del Guer.).

Epidiaspis piricola (Del Guer.).

rosae (Bouché).

Genus AULACASPIS Ckll.

Genus EPIDIASPIS Ckll.

Regarded as a synonym of Diaspis.

piricola (Del Guer.).

Diaspis piricola (Del Guer.).

*kelloggi Coleman.

Genus LEUCASPIS Targ.

*Dinaspis kelloggi (Coleman).

*kelloggi (Coleman).

Genus DINASPIS Leon.

*Leucaspis kelloggi Coleman. 


\section{Genus LEPIDOSAPHES Shimer.}

newsteadi (Sulc).

ulmi (Linn.).

Genus ASPIDIOTUS Bouché.

arctostaphyli Ckll. and Rob.

*aesculi Johns.

abietis Comst. (misidentification). pini Comst.

californicus Coleman. pini Comst.

coniferarum Ckll.

coniferarum var. shastae Coleman. shastae Coleman.

densiflorae Bremner.

ehrhorni Coleman.

hederae (Vall.)

osborni Ckll.

yulupae Bremner.

perniciosus Comst.

pini Comst.

abietis Comst. (misidentification).

californicus Coleman.

rapax Comst.

shastae Coleman.

coniferarum var. shastae Coleman.

yulupae Bremner.

osborni Ckll.

Genus CHRYSOMPHALUS Ashmead.

rossi (Maskell).

dearnessi Ckll.

Genus TARGIONIA Sign.

Genus ODONASPIS Leon.

*graminis Bremner. 


\title{
DISCUSSION OF GENERA AND SPECIES
}

\author{
Genus ICERYA Sign. \\ Icerya purchasi Maskell.
}

It will be remembered that this species was originally introduced into the United States at a point in this area. At the present time it occurs rather commonly here, being somewhat of a pest on the pears in the Santa Clara Valley and occasionally killing ornamentals. It has established itself on certain wild plants, especially favoring mistletoe, but also occurring on sage brush (Artemisia californica) and chamiso (Adenostoma fasciculatum).

\section{Genus XYLOCOCCUS Loew.}

\section{Xylococcus quercus Ehrh.}

1917. Xylococcus quercus Ehrh.; Florence, Ann. Ent. Soc. Am., 10:155-8; figs.

1919. Xylococcus quercus Ehrh.; Ferris, Can. Ent., $51: 110$.

Originally described from Quercus chrysolepis, Stevens Creek Canyon, near Mountain View, in this area. I have taken what is probably the same species from Quercus californicus in the hills above Searsville Lake. The species appears to be rather rare and very local in occurrence.

As I have elsewhere pointed out (ref. cited) it is somewhat doubtful that this species is distinct from $X$. betula Perg. I have specimens of all the critical stages of both species and find that the two differ only in the number of median, ventral pores in the first larval stage, betula having five or six of these pores and quercus two. However, in specimens from Quercus californicus there are as many as nine of these pores. Either the specimens from the two species of oaks should be regarded as separate species or both should be referred to betula. I am inclined to favor the latter view, but the examination of more material is desirable.

\section{Genus STOMACOCCUS Ferris.}

1917. Ferris, Can. Ent., $49: 375$.

This genus was originally based chiefly upon the presence of mouthparts in the adult female, but this character is not sufficient to distinguish it, as other genera of this group are now known to possess mouthparts in the adult female. I append the following recharacterization of the genus. 
Monophleboid Coccidæ in which the legs are lacking in the intermediate stages of the female; immature stages without an anal tube; adult female with mouthparts, with digitules on the claw and without knobbed hairs at the tip of the tibia, without reticulations on the legs and antennæ, with 7-segmented antennæ; all stages (except perhaps the first) with six pairs of abdominal spiracles; adult male wingless, without compound eyes.

Notes: It is possible that this genus should be merged with Steingelia, but the male of $S$. britannica (Green) is winged. Until the intermediate stages of Steingelia have been described it may be well to maintain the two genera as distinct.

\section{Stomacoccus platani Ferris.}

Originally described from this area where it is abundant on the native sycamore, Platanus racemosa. It has also been taken from $P$. occidentalis, an introduced species within this area.

Genus ORTHEZIA Bosc.

Orthezia occidentalis Douglas.

Orthezia californica Ehrh. appears to be the same as O. occidentalis. I have received a specimen of the latter from Professor Cockerell and am unable to detect any differences.

This species is rather common, occurring on the crowns and roots of various plants, especially Eriophyllum confertiflorum. I have once taken it from cells in the hard, dry soil clinging to the roots of a species of Dudleya on the cliffs near New Years Point.

Genus ASTEROLECANIUM Targ.

Asterolecanium variolosum (Ratz.).

Common on Quercus agrifolia, Q. lobata, and Q. douglasii.

Genus MYCETOCOCCUS Ferris.

Mycetococcus ehrhorni (Ckll.).

1918. Mycetococcus ehrhorni (Ck11.); Ferris, Can. Ent., 50:330, fig. 15A.

This species (formerly referred to Cerococcus) was originally described from this area. It occurs only on oaks and probably infests all the local species (including the tan oak, Pasania densiflora). It especially favors the live oak, $Q$. agrifolia, the limbs of which are frequently gray with the fungus which is invariably associated with the insect. 


\section{Genus EHீRHORNIA Ferris.}

\section{Ehrhornia cupressi (Ehrh.).}

1918. Ehrhornia cupressi (Ehrh.); Ferris, Can. Ent., $51: 326$.

A serious pest on Cupressus macrocarpa and $C$. guadelupensis, which are extensively grown as ornamentals throughout this region. It also occurs on Libocedrus decurrens on the campus of Stanford University.

\section{Ehrhornia graminis Ferris.}

1918. Ehrhornia graminis Ferris, Can. Ent., 51:326, fig. 12 .

Within this area this species has been taken only from the rootstocks of an undetermined perennial grass growing in the brush on the hills above Scott Creek, Santa Cruz County.

\section{Genus PALUDICOCCUS Ferris.}

Paludicoccus disticlium (Kuwana).

1918. Paludicoccus disticlium (Kuwana); Ferris, Can. Ent., 50:327, fig. 13.

Known only from a grass, Distichlis spicata, in the salt marshes about San Francisco Bay.

\section{Genus ERIOCOCCUS Targ.}

The present author has had the opportunity of examining specimens of nearly all the species of this genus that have been recorded from North America. In the course of this study it has become apparent that most of the existing descriptions of species are quite inadequate, owing to the fact that too much attention has been paid to characters of but little importance, while those of genuine value have been quite consistently ignored.

The character of the sac is in a few cases of some value, but in general has little significance, there being practically no difference between the sacs of widely differing species. In only a few extreme cases is it important. The character of the legs likewise is of but little use, except in some extreme cases. The antennæ are undoubtedly worthy of some consideration, although the antennal formulæ that have been so extensively used are probably of no special value. The most distinctive characters are to be found in the form, number, and distribution of the spines with which the body is generally more or less thickly beset. In a few cases it appears that the form of the wax ducts may be of some slight use.

Even with the aid of these characters it is often difficult to decide as to the proper disposition of specimens. The amount of material at present 
available is not large, but it is sufficient to indicate that there is either an extraordinary amount of variation or that an indefinite number of species separated by infinitesimally small characters must be recognized. The examination of a large mass of material is needed before very definite conclusions may safely be formed.

\section{Eriococcus adenostomæ Ehrh. Fig. 2.}

Originally described from this area where it is quite common on Adenostoma fasciculatum. It has been recorded from this host in the southern part of the state also.

Adult female with spines present both on dorsum and margins of the body. Spines rather few, of varying sizes, those of the margins not



Fig. 2.-Eriococcus adenostoma Ehrh.: $A$, antenna of adult female; $B$, anal lobes, dorsal aspect left, ventral aspect right; $C$, types of spines; $D$, wax duct. From specimen from topotype material.

or but little larger than those of the dorsum, all small but relatively stout and for the most part slightly curved, tapering regularly to the blunt apex (Fig. 2C). On each abdominal segment there is a group of three or four spines at each lateral margin, a median group and a submedian group of two or three spines on each side. Anal lobes (Fig. 2B) but little, or not at all, chitinized, each with three spines on the dorsum, which are smaller than the largest body spines, and with two slender setæ on the ventral side. Ducts (Fig. $2 D$ ) with a deep and rather narrow cup at the inner extremity. Antennæ (Fig. $2 A$ ) noticeably short and stout, normally 7 -segmented. Legs likewise rather short and stout, the claw with a distinct tooth beneath. Posterior coxæ bearing numerous rather large pores. 


\section{Eriococcus araucariæ Maskell.}

Fig. 3.

1915. Eriococcus araucariae Maskell; Essig, "Injurious and Beneficial Insects of California," ed. 2, p. 120, fig. 102.

This is an introduced species found only on Araucaria. It probably is generally distributed within this area wherever its host is grown, but I have seen specimens only from Menlo Park.

Essig (ref. cited) has given an excellent photograph of the sac, and I append herewith a description of the morphological characters of the species.


Fig. 3.-Eriococcus araucarice (Maskell) : $A$, antenna of adult female; $B$, anal lobes, dorsal aspect left, ventral aspect right; $C$, types of spines, the smallest representing those of the dorsum; $D$, wax duct. From specimen from Santa Cruz Peninsula.

Adult female with the marginal spines greatly exceeding in size those of the dorsum (Fig. $3 C$ ), the latter being quite numerous but very small, cylindrical and truncate at the tip, the former being straight, slightly expanded at the base and then tapering evenly to the tip, which is bluntly rounded or even truncate. The marginal spines are arranged in a definite single row, each abdominal segment bearing three spines at each lateral margin, one of these spines being considerably smaller than the other two. Anal lobes (Fig. $3 B$ ) heavily chitinized, rather cylindrical in form, each bearing upon the dorsum three spines of about the size of the smaller marginal spines and upon the ventral side a pair of slender setæ. Anal lobe setæ somewhat longer than the anal ring setæ. Antennæ (Fig. $3 A$ ) 
normally 7-segmented, rather long and slender. Legs likewise rather slender, the claw without a tooth, and the posterior coxæ without pores. Ducts (Fig. 3D) with a rather broad and deep cup.

Notes: Of the species known to me this most closely resembles $E$. coccineus Ckll., which is found on cactus, but the latter differs in having the marginal spines more numerous and in having a few large spines on the dorsum of the cephalothorax.

\section{Eriococcus bahiæ Ehrh.}

Fig. 4.

Originally described from the roots of Eriophyllum (=Bahia) confertiflorum, from this area. It occurs quite commonly on this host, and

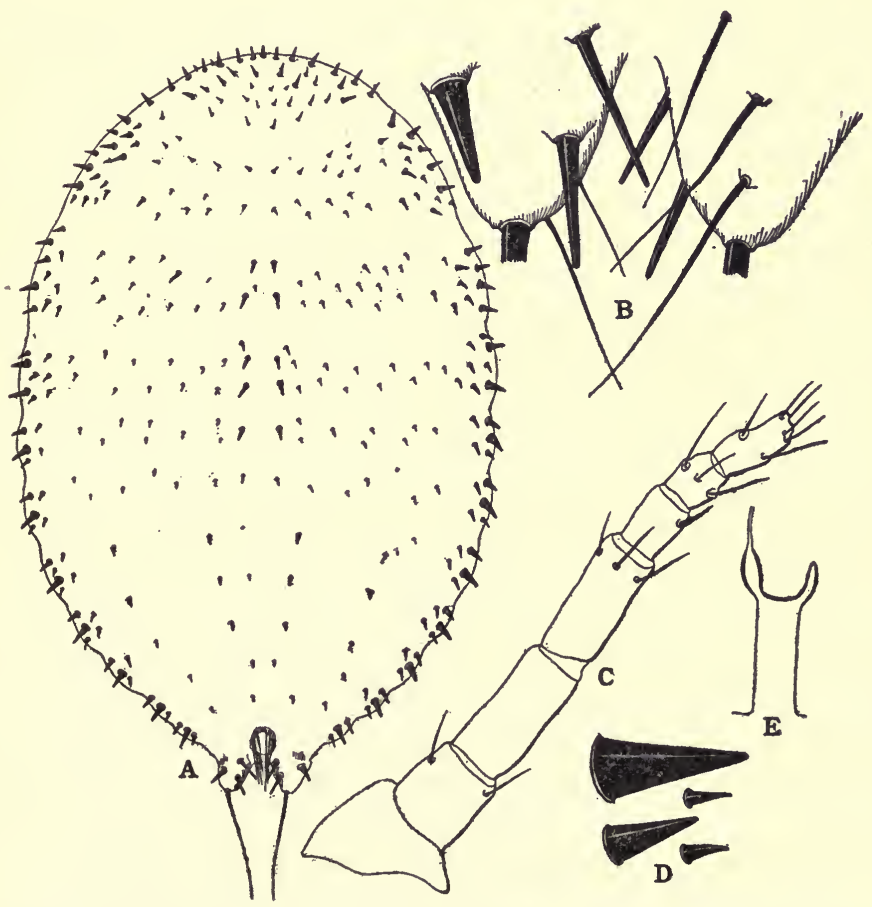

Fig. 4.-Eriococcus bahice Ehrh.: $A$, dorsal aspect of adult female; $B$, anal lobes, dorsal aspect left, ventral aspect right; $C$, antenna of adult female; $D$, types of spines; $E$, wax duct. From specimen from type material. 
I have specimens from Castilleia sp. near Woodside, grass near Stanford University and Quercus agrifolia near Mountain View that I assign to this species.

Adult female (Fig. $4 A$ ) with the spines of the margins much larger than those of the dorsum, the latter usually quite small. Marginal spines (Fig. 4D) (in specimens from the type material) very stout, conical and rather bluntly pointed, of various sizes, each abdominal segment normally with one or two large spines and two or three smaller spines at each lateral margin. Dorsal spines (Fig. $4 D$ ) resembling those of the margins in form or at times slightly curved, rather few in number, those of the abdomen tending to be arranged in four longitudinal rows, those of the cephalothorax more numerous, scattered, in size merging at the margins with the marginal spines. Anal lobes (Fig. $4 B$ ) chitinized only along the mesal margin, each with three slender ventral setæ and three dorsal spines of which two are longer and more slender than the marginal spines. Anal lobe setæ nearly three times as long as the anal ring setæ. Antennæ (Fig. 4C) moderately slender, normally 7 -segmented. Legs likewise moderately slender, the claw with a distinct tooth, the posterior coxæ with a few pores. Ducts (Fig. $4 E$ ) with a rather deep and slightly asymmetrical cup.

Notes: The above description and the accompanying figures are based upon specimens from the type material, but the species presents a very consideralle range of variation. Even in specimens from the type host and the immediate type locality the marginal spines are noticeably longer and more slender than those here figured.

I have at hand a considerable amount of material from localities without this area which represents either extreme variations of $E$. bahiae or several very closely related species. In this material are specimens of E. costaricensis Ckll., which differ only in having the spines of the anal lobes slightly smaller than the marginai spines and in having the anal lobes mcre heavily chitinized; specimens from Eriogonum sp. in Owens Valley, California, which differ in having the marginal spines stouter than in E. bahiae; specimens from Gutierrezia sp. near Mesilla Valley, New Mexico, which differ only in having the marginal spines slightly curved, and specimens from the material recorded by Cockerell as E. palmeri var. $a$ which differ in having the marginal spines larger and slightly differently shaped. Only the examination of a large amount of material from many hosts and localities will permit any definte conclusions as to the proper disposition of these forms.

\section{Eriococcus pænulatus n. sp.}

Fig. 5.

Type host and locality. From Artemisia californica, near Stanford University, California.

Habit. Occurring on the smaller stems of the host. Sac white, smooth except for a few projecting threads of wax; length $2.5-3 \mathrm{~mm}$. 
Morphological characteristics. Spines rather few but present over the entire surface of the dorsum, not arranged in definite rows. The spines are of various sizes, but the largest of the marginal spines are scarcely or not at all larger than those of the dorsum. In form (Fig. 5) they vary from moderately to very stout and are for the most part straight or very slightly curved, slightly expanded at the base and then

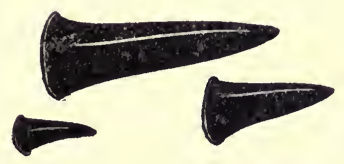

Fig. 5.-Eriococcus panulatus n. sp.; types of spines.

tapering in a smooth curve to the bluntly rounded apex. Anal lobes weakly chitinized, each with two slender setæ on the ventral side and three spines on the dorsal side, these somewhat more slender but about the same length as the largest of the body spines. Antennæ 7-segmented. Legs with the tarsus slightly longer than the tibia, the claw with a tooth, the posterior coxæ without pores. Tubular ducts with the cup quite deep, nearly symmetrical. Anal ring with eight setæ, the longest of which are about half as long as the anal lobe setæ.

Notes: I have found this species in but a single restricted locality and there in but small numbers. It somewhat resembles $E$. villosus n. sp., the description of which follows, but the spines are consistently stouter, larger and more bluntly tipped and the posterior coxae are destitute of all but a very few minute pores.

\section{Eriococcus quercus (Comst.)}

Fig. 6.

1915. Ericoccus quercus (Comst.); Essig, "Injurious and Beneficial Insects of California," ed. 2, p. 121, fig. 103.

Within this area this species has been taken only from Quercus agrifolia at Palo Alto. It is a widely distributed species, occurring throughout the United States on various species of oaks.

Essig (ref. cited) has given an excellent figure of the sac, and a description of this may be omitted, but I append the following notes on the insect itself.

Adult female with the dorsum uniformly beset with numerous rather large, slender, tapering, curved, and slightly pointed spines (Fig. $6 C$ ), those along the margins being somewhat larger than the others. Anal lobes (Fig. $6 B$ ) heavily chitinized, rather cylindrical, their mesal margins 
bearing a number of small, tubercle-like projections, the dorsum with three spines of the same size and shape as those of the body, and the ventral side with a single slender seta. Anal lobe setæ scarcely longer

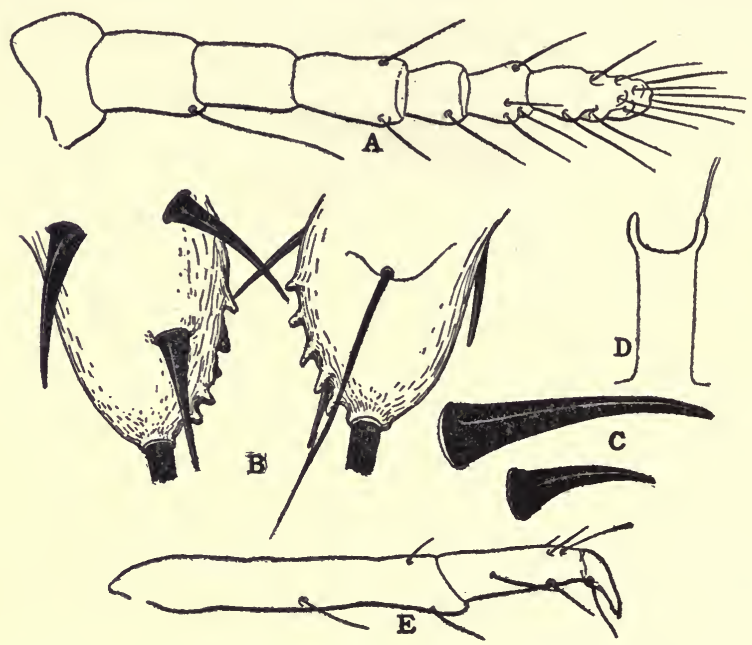

Fig. 6.-Eriococcus quercus (Comst.): $A$, antenna of adult female; $B$, anal lobes, dorsal aspect left, ventral aspect right; $C$, types of spines; $D$, wax duct; $E$, tibia and tarsus. From specimen from Quercus agrifolia, on the Santa Cruz Peninsula.

than the anal ring setæ. Antennæ (Fig. $6 A$ ) rather slender, 7-8-segmented. Legs (Fig. $6 E$ ) quite slender, the tibia always much exceeding the tarsus in length, the claw with a small tooth, the posterior coxæ without pores. Tubular ducts (Fig. $6 D$ ) with a broad and shallow cup.

Notes: This is a very distinctive species, the form of the spines, the unusual length of the tibia and the tubercles on the anal lobes separating it at once from the other North American representatives of the genus. I have at hand specimens from several localities and while there is evidently a considerable variation in the size of the dorsal spines, these in some cases being much smaller than those of the margin and in others nearly or quite as large, the other characters are so constant that I consider all to belong to the same species. I have not seen the types of E. howardi Ehrh. but it is in all probability the same.

The description given above is from specimens from Quercus agrifolia at Palo Alto. 


\section{Eriococcus stanfordianus n. sp.}

Fig. 7.

Type taken from beneath a stone on Jasper Ridge, near Stanford University, California, November, 1917.

Sac. Character not noted.

Morphological characteristics. Body (Fig. $7 \mathrm{~A}$ ) beset with numerous large spines (Fig. $7 B$ ), all of which are straight, slightly expanded at the base, tapering thence to the sharply pointed tip. The spines of the

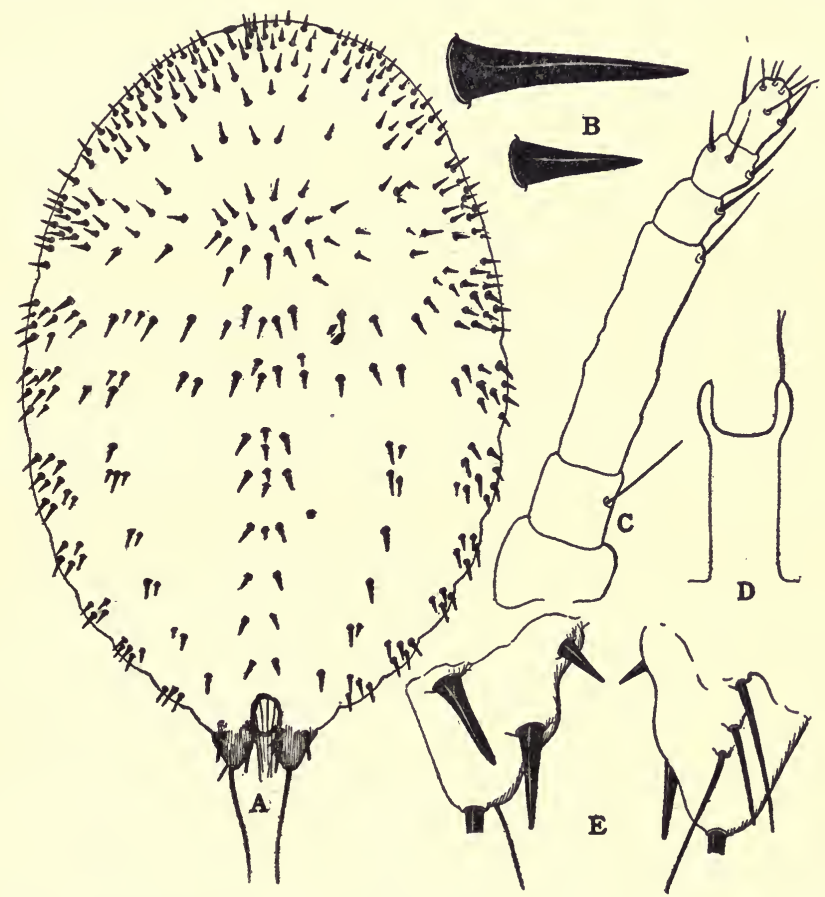

Fig. 7.-Eriococcus stanfordianus n. sp.: $A$, dorsal aspect of adult female; $B$, types of spines; $C$, antenna of adult female; $D$, wax duct; $E$, anal lobes, dorsal aspect left, ventral aspect right.

margin do not exceed in size those of the dorsum. On the abdomen the spines are arranged in a quite definite manner, there being on each segment a median group of two or three, one or two spines midway between this group and each margin, and a marginal group of five or six on each 
side. On the cephalothorax the spines are more numerous and are irregularly arranged. Anal lobes (Fig. $7 E$ ) weakly chitinized, each with three slender setæ on the ventral side and three spines on the dorsal side which are of the same shape as the body spines. Antennæ (Fig. 7C) rather stout, 6-segmented, the third segment being very long. Legs rather slender, the claw with a very small tooth, the posterior coxæ without pores. Ducts (Fig. 7D) with a rather broad and shallow cup. Anal ring with eight setæ which are about half as long as the anal lobe setæ.

Notes: I have but a single specimen of this species from this locality. Certain specimens from Chamaecyce polycarpa between Mecca and Blythe, Riverside County, Calif., resemble it in the arrangement of the spines and in the character of the antennae but differ in having the spines smaller and blunter. I am inclined to refer them to this species.

\section{- Eriococcus villosus n. sp.}

Fig. 8.

Type host and locality. From Eriogonum latifolium, New Year's Point, Santa Clara County, California, September, 1918.

Sac slightly yellowish, its surface with many projecting filaments of wax. All the specimens observed were on the under surface of the leaves, the color and roughness of the sac causing them to resemble very closely the thick tomentum of the leaf.

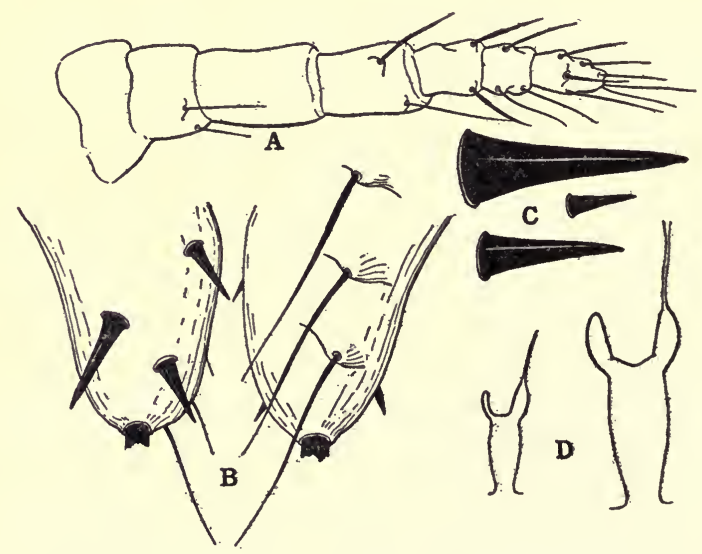

Fig. 8.-Eriococcus villosus n. sp.: $A$, antenna of adult female; $B$, anal lobes, dorsal aspect left, ventral aspect right; $C$, types of spines; $D$, wax ducts. 
Morphological characteristics. Dorsum quite uniformly beset with moderately large spines (Fig. $8 \mathrm{C}$ ) of various sizes, which are straight, somewhat expanded at the base, tapering thence to the sharp point, those of the margins but little or not at all larger than those of the dorsum. Anal lobes (Fig. $8 B$ ) weakly or not at all chitinized, each with three slender setæ on the ventral side and three spines on the dorsal side, these resembling the majority of the body spines in form and size. Antennæ (Fig. $8 \mathrm{~A}$ ) moderately stout, 7 -segmented. Legs rather slender, the tibia and tarsus sub-equal, the claw with a tooth, the posterior coxæ with many pores on one side. Ducts (Fig. $8 D$ ) of two sizes, both with the cup quite deep, the smaller with it somewhat asymmetrical. Anal ring with eight setæ, which are about half as long as the anal lobe setæ.

Notes: It is possible that this is E. dubius Ckll., which is a species of very similar character, but I can not definitely connect the two and prefer to give this a name. I have at hand specimens from Acacia paucispina, Prosopis velutina and $P$. glandulosa all taken in Arizona, which are possibly this species.

\section{Genus GOSSYPARIA Targ.}

\section{Gossyparia spuria (Modeer).}

Very abundant on elms on the campus of Stanford University and probably to be found in other parts of this area.

\section{Genus KERMES Boitard.}

This genus seems in general to have been somewhat misunderstood, probably in large part because the adults are difficult to study morphologically and because the immature stages have been studied but little. The genus has been placed by some authors in a distinct subfamily, the Hemicoccince. It should be pointed out that if such a subfamily be recognized the name should stand as Kermesince, there being no genus Hemicoccus. Cockerell, however, has assigned the genus to the tribe Eriococcini of the subfamily Dactylopiince, a position that is without much doubt correct. At least the genus is a member of the group (whatever value may be assigned to it) to which Eriococcus belongs. The first stage larva, the wax ducts and the antennæ are strictly of the Eriococcine type.

The separation of the various species of this genus has usually been attempted from a consideration of the adult female without reference to morphological characters. Owing to the extreme chitinization of the derm at maturity it is practically impossible to obtain slide mounts in which anything of value can be seen; but if specimens be taken early in the last instar, before this chitinization has begun, the various structures 
can easily be made out. The examination of specimens in this stage will doubtless clear up many questions as to synonymy and should be regarded as an essential part of any studies upon the genus.

As far as I can discover the development of no species of this genus has yet been carefully described. I am therefore discussing at some length the development of Kermes cockerelli.

\section{Kermes cockerelli Ehrh.}

Figs. $9 C, 10$ and 11 .

Originally described from this locality. It has been taken only from Quercus lobata.

Habit (Fig. 9C). Entirely devoid of secretionary covering; color a uniform light brown. There is a deep, median furrow along which there is little or no indication of segmentation, but at the sides of the furrow the intersegmental constrictions are very deep, causing the sides to be extremely gibbous.
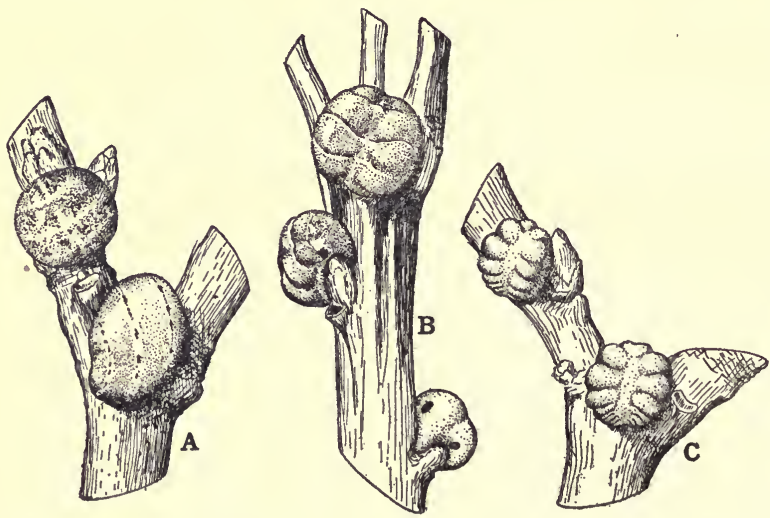

Fig. 9.-A, Kermes rattani Ehrh.; B, Kermes nigropunctatus Ehrh.; $C$, Kermes cockerelli Ehrh.

Morphological characteristics. Specimens of the adult female taken before the derm becomes heavily chitinized (Fig. 10B). Antennæ (Fig. $10 \mathrm{~A}$ ) short and stout, obscurely 6-segmented with the third segment longest. Legs likewise short and stout, but presenting all the normal parts. Anal lobes represented only by a pair of weakly chitinized areas, each of which bears several small spines. In fully grown specimens these 
lobes become almost obliterated. Anal ring borne at the inner end of a short invagination, consisting of a simple, irregular, chitinized ring which bears no setæ. Body with a few stout, sharply pointed spines (Fig. 10D) at the margins. Extending almost around the ventral side of the body is a broad zone containing many tubular ducts which have the inner ex-

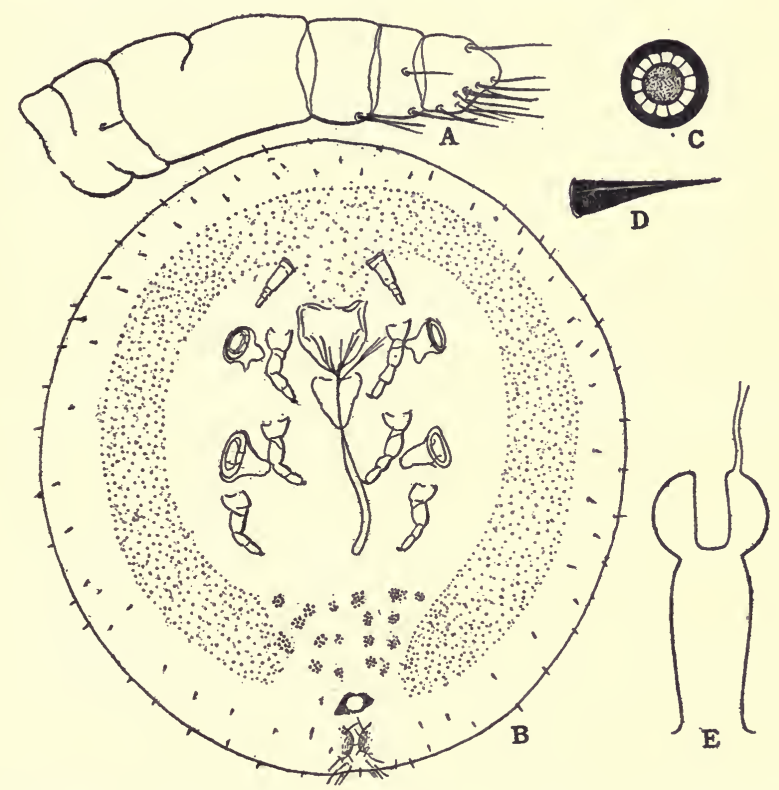

Fig. 10.-Kermes cockerelli Ehrh.; $A$, antenna of adult female; $B$, adult female before the hardening of the derm; $C$, pore from ventral cluster; $D$, dorsal spine; $E$, wax duct. From specimen from topotype material.

tremity reflexed into a very deep and narrow cup (Fig. 10E). Behind the posterior legs are numerous clusters of circular, multilocular pores of the type shown in Fig. 10C.

In the penultimate stage (Fig. $11 B$ ) the body is oval in form and shows small anal lobes. The lateral margins are beset with numerous slender spines. The antennæ (Fig. 11D) are 6-segmented as in the adult but much slenderer. Anal ring with six setæ. Tubular ducts lacking. 
First stage larva (Fig. 11A), with the anal lobes well developed and rather heavily chitinized. Margin of the body with a single row of slender

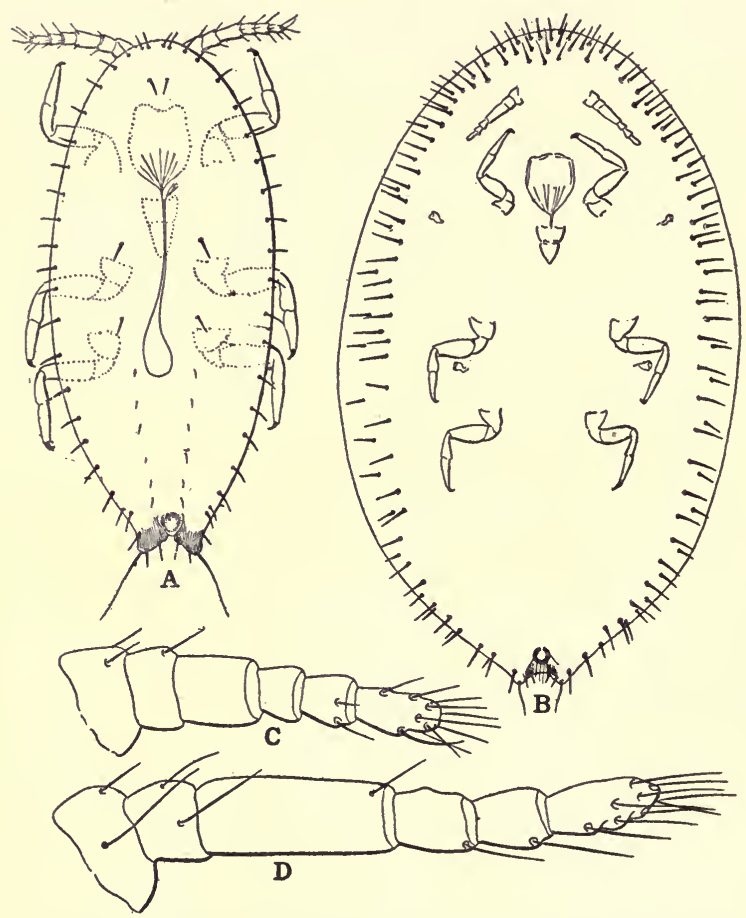

Fig. 11.-Kermes cockerelli Ehrh.: $A$, first stage larva; $B$, second stage; $C$, antenna of first stage; $D$, antenna of second stage. From specimens from topotype material.

spines. Antennæ (Fig. 11C) 6-segmented, of the same type as in the other stages. Dorsum without spines except for a pair of very small spines on each abdominal segment and two or three pairs of larger spines on the cephalothorax.

\section{Kermes nigropunctatus Ehrh.}

Figs. $9 B$ and 12 .

Within this area this species has been taken from Quercus agrifolia and $Q$. wislizeni. 
Habit. Adult entirely destitute of secretionary covering. The color is extremely variable, some specimens being very dark and others quite pale, this variation depending in part upon actual variability, in part upon the amount of weathering undergone before collection and in part upon the age of the insect at the time of death. In all specimens, however, there is a pair of black, eye-like spots at the anterior end of the body, a character that seems effectually to mark the species.
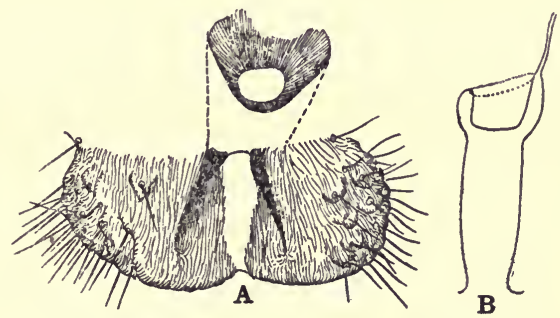

Fig. 12.-Kermes nigropunctatus Ehrh.: $A$, anal lobes and anal ring of adult female; $B$, wax duct. From specimen from Quercus wislizeni, on the Santa Cruz Peninsula.

In form (Fig. 9B) the adult somewhat resembles $K$. cockerelli, but the intersegmental constrictions are much shallower and the insect is only slightly gibbous.

Morphological characteristics. In specimens in the last instar, but taken before the chitinization of the derm has begun, the anal lobes (Fig. $12 A$ ) appear as a pair of heavily chitinized, wart-like prominences, each of which bears many slender setæ. The anal ring is borne at the inner end of a short invagination, is heavily chitinized, somewhat funnelshaped, and bears no setæ. The dorsum bears a few stout, sharply pointed spines. The tubular ducts are few and small, of the form shown in Fig. $12 B$ and are scattered over the body, not being arranged in a ventral zone as in $K$. cockerelli. The groups of circular pores found on the venter of the latter species are lacking in $K$. nigropunctatus. Antennæ and legs as in cockerelli.

Immature stages not seen.

Notes: I consider Kermes essigi King to be identical with $K$. nigropunctatus. I have at hand specimens from what is possibly the type lot of the former species and am unable to detect any differences between the two. In this opinion Mr. Ehrhorn concurs. Furthermore if certain specimens at hand purporting to be $K$. branagani King are correctly determined this species too is a synonym of nigropunctatus. 


\section{Kermes rattani Ehrh.}

Fig. $9 \mathrm{~A}$.

Originally described from Quercus chrysolepis in this locality.

I have been able to obtain only fully mature individuals of this species and can say nothing as to its morphology. In appearance the species presents a wide range of variation both in form and coloring. The typical form is practically spherical, but various distortions arise because of unfavorable position.

Judging from the figure of Kermes mirabilis King and from the fact that its type locality is the same as that of $K$. rattani this species may quite safely be regarded as identical with $K$. rattani. Mr. Ehrhorn concurs in this opinion also.

\section{Genus PSEUDOCOCCUS Westwood.}

In an earlier paper ${ }^{1} \mathrm{I}$ have dealt at some length with this and related genera. More material is now available than at the time when this paper was published, and certain conclusions there expressed require modification. In addition certain errors, both of observation and judgment, may be corrected.

In this earlier paper the genera Phenacoccus and Pseudococcus were in part separated by ascribing eighteen pairs of cerarii to the former genus and seventeen to the latter. A re-examination of my material indicates a serious error in observation. In Pseudococcus citri and $P$. kraunhiae there are in fact eighteen pairs, although $P$. longispinus and some other species have but seventeen. This character, therefore, cannot be relied upon for the separation of these genera. Neither may the number of antennal segments be considered as decisive, since there are some species, notably Phenacoccus solani Ferris, in which the antennæ may be either eight- or nine-segmented. Nor is the single remaining character, that of the presence of a denticle on the claw in Phenacoccus, entirely satisfactory, as this denticle is at times so extremely small as practically to be obsolete.

I am by no means prepared to concede that these two genera should be united, for their types are certainly sufficiently different, and it is probable that a large majority of species may be placed satisfactorily. Neither am I prepared to say just where the division between the two genera should come. This particular difficulty is but one of a series of difficulties that arise in dealing with this group, as I have elsewhere pointed out. ${ }^{2}$ The difficulties may not be disposed of without the examination of a much larger series of forms than have yet been studied.

1 "The California Species of Mealy Bugs." Stanford University Publications, University Series. 1915.

2 "Contribution to the Knowledge of the Coccidae of Southwestern United States,” p. 31. Stanford University Publications, University Series. 1919. 
Pseudococcus aurilanatus (Maskell).

An introduced species, reported from within this area only on Araucaria excelsa at Mountain View.

\section{Pseudococcus gahani Green.}

1919. Pseudococcus gahani Green; Ferris, Jn. Ec. Ent. 12 :292.

This is an introduced species, known from this area only from Hillsborough and San Francisco. It infests a wide range of hosts.

I have elsewhere (ref. cited) pointed out that this is the proper name for the species that has passed under the name of Pseudococcus citrophilus Clausen.

\section{Pseudococcus crawii (Coq.).}

Within this area this species has been taken only from Quercus chrysolepis and Pasania densiflora.

\section{Pseudococcus eriogoni (Ehrh.).}

Originally described from Eriogonum sp. in this area. It occurs commonly on this and several other hosts.

\section{Pseudococcus longisetosus Ferris.}

Described from this area. It has been taken from the roots of Orobanche tuberosa and Castilleia foliolosa.

\section{Pseudococcus maritimus Ehrh.}

Originally described from Eriogonum latifolium at Santa Cruz. It occurs throughout the area on a wide range of wild and cultivated hosts.

\section{Pseudococcus quercus Ehrh.}

1919. Pseudococcus quercus Ehrh.; Ferris, Jn. Ec. Ent. 12 : 298.

Originally described from this area where it occurs quite commonly on Quercus chrysolepis and Pasania densiflora.

I have elsewhere (ref. cited) explained the reasons for the resurrection of this name and the dropping of Pseudococcus quercicolus Ferris.

\section{Pseudococcus ryani (Coq.).}

Occurring within this area only on Sequoia sempervirens.

Pseudococcus salinus (Ckll.).

A native species, found only on the salt marsh grass, Distichlis spicata, in the marshes about San Francisco Bay. 
Pseudococcus sequoiæ (Coleman).

Originally described from this area, where it is common on Sequoia sempervirens and is at times a pest on Cupressus macrocarpa.

\section{Pseudococcus timberlakei Ckll.}

Originally described from this area, where it is found only on the salt marsh grass, Distichlis spicata, about San Francisco Bay.

\section{Genus PHENACOCCUS Ckll. \\ Phenacoccus colemani Ehrh.}

Originally described from this area on Rubus sp. It is a rather common species, infesting various hosts among which are $R$ ubus vitifolius, wild strawberry, Symphoricarpos racemosus, Castilleia sp. and Eriophyllum confertiflorum.

\section{Phenacoccus eriogoni Ferris.}

Originally described from this area on Eriogonum nudum

This species is extremely close to $P$. helianthi (Ckll.). It differs from the latter only in having a small, median cluster of spines on the dorsum of the last abdominal segment and in having six to eight spines in the lateral cerarii, while helianthi has in general but two.

\section{Phenacoccus solani Ferris.}

Originally described from this locality on the roots of Hemizonia rudis. It has also been taken from the roots or crowns of potato, tomato, wild radish and Malva sp.

I have recently received specimens of this species from the crowns of "ragweed," Ambrosia sp., at Gainesville, Florida. In these specimens the antennæ may be either eight- or nine-segmented.

This species so combines the characters of Phenacoccus and Pseudococcus that it might with equal propriety be referred to either genus. I am inclined to retain it in Phenacoccus.

\section{Phenacoccus stachyos Ehrh.}

Originally described from this area on Stachys sp. I have taken it from several other hosts, including Rhus diversiloba, Monardella sp., Diplacus glutinosus and Solanum sp. 


\section{Genus PUTO Sign. \\ Puto cupressi (Coleman).}

A native species, occurring in this area on Sequoia sempervirens and Torreya californica.

\section{Puto ambigua (Fullaway).}

A native species, originally described from this area, where it is known only from the "pickleweed,".Salicornia ambigua, in the salt marshes about San Francisco Bay.

\section{Puto yuccæ (Coq.)}

A native species which occurs quite commonly in this area on Eriophyllum confertiflorum. It has also been taken from Garrya elliptica, Diplacus glutinosus and Stachys sp.

\section{Genus ERIUM Ck11.}

Erium lichtensioides Ckll.

A native species, occurring sparingly on sage brush, Artemisia californica.

\section{Genus TRIONYMUS Berg.}

\section{Trionymus bromi Ferris.}

A presumably native species, originally described from this area on Bromus sp. It has also been taken from Ammophila arenaria (an introduced grass) on the sand dunes at San Francisco.

\section{Trionymus californicus Ehrh.}

A native species which is rather common on various species of Elymus.

\section{Trionymus distichlii Ferris.}

A native species, originally described from this area, where it is known only from the salt marsh grass, Distichlis spicata, in the salt marshes about San Francisco Bay and along the coast.

\section{Trionymus festucæ (Kuwana).}

A native species, originally described from this area on Festuca sp. In my paper on the California species of this group I have included with this species a Trionymus that occurs on bamboo on the Stanford Campus. I am now inclined to believe that the two are not identical. 
Trionymus smithii (Essig).

From undetermined grass near Stanford University and Elymus sp. near San Jose.

\section{Trionymus villosa (Ehrh.).}

I have not myself taken this species in this area, but there are specimens in the Stanford collection from Quercus agrifolia near Mountain View.

\section{Trionymus sp.}

An undetermined Trionymus on bamboo on the Stanford campus. I have previously included this with $T$. festucae but now regard it as distinct. It is doubtless introduced.

\section{Genus ACLERDA Sign. \\ Aclerda californica Ehrh.}

Fig. 13.

Originally described from this area, where it occurs quite commonly on a particular, unidentified species of grass that grows in the chaparral

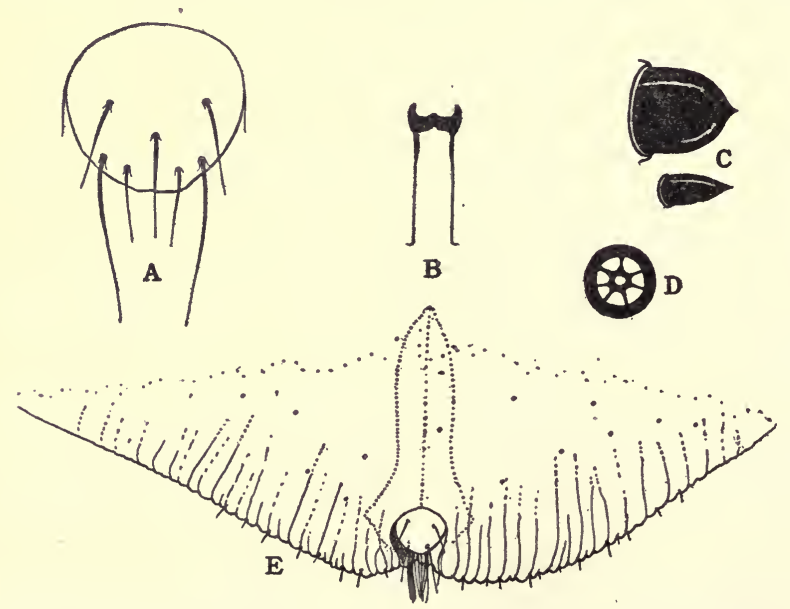

Fig. 13.-Aclerda californica (Ehrh.) : $A$, anal plate; $B$, wax duct; $C$, types of marginal spines; $D$, pore; $E$, dorsal aspect of posterior extremity of abdomen of adult female. From specimen from topotype material. 
on dry hillsides. The insects are ordinarily found at the bases of the stems. Parrott has recorded the species from Kansas, but has noted certain differences between the specimens from the two regions. It is quite possible that he was dealing with a different form.

The general appearance of the adult female has been well described by Ehrhorn and Parrott, but there remain certain important details of structure that have been overlooked.

In the adult female the posterior end of the body (Fig. 13E) is heavily chitinized, although this area is not definitely delimited as in A. ariditatis Ferris, the margin is crenulate and both dorsum and venter show numerous shallow furrows. The margins of this chitinized portion are beset with small, slender spines. Beginning at the anterior margin of this area is an irregularly single or double row of short, stout, acornshaped spines (Fig. 13C), that extends entirely around the anterior portion of the body. These spines are of various sizes, but all are of the same characteristic shape, broad and short, very slightly or not at all constricted at the base and with the apex produced into a sharp point. Just within this series of spines lies a zone of rather conspicuous, multilocular pores (Fig. 13D), this zone disappearing on the head and widening opposite the spiracles. Within this zone are a few slender spines, and distributed irregularly over the body are a few tubular ducts of the type shown in Fig. 13B.

The anal plate (Fig. 13A) is not emarginate at the tip. It bears several setæ. The anal ring lies immediately beneath this plate (not anteriorly to it as in some species). The edges of the ventral furrow, which is continuous with the anal cleft, are contiguous and heavily chitinized.

\section{Aclerda tokionis Ckll.}

Fig. 14.

This is an introduced species, probably a native of Japan, which has once been taken from bamboo on the Stanford campus. Specimens from this material agree entirely with specimens from Japan.

This species differs in certain conspicuous details from the preceding. The marginal spines (Fig. 14B) are smaller and quite differently shaped, being blunt-tipped and definitely constricted toward the base. The marginal series of these spines extends almost to the margins of the anal cleft. The zone of multilocular pores seen in A. californica is lacking, being replaced by a similarly situated zone of small, straight tubular ducts which are mingled with a few large ducts of the type shown in Fig. $13 B$ and a few small spines. The anal plate (Fig. 14C) is distinctly 
emarginate at the tip. The anal ring lies directly beneath the anal plate. The ventral furrow is open, its margins diverging anteriorly and not heavily chitinized.

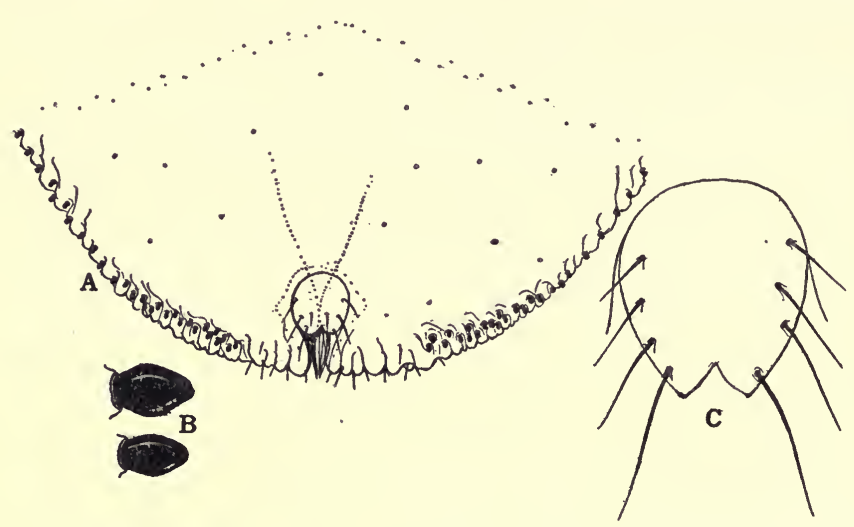

Fig. 14.-Aclerda tokionis (Ck11.) : A, dorsal aspect of posterior extremity of abdomen of adult female; $B$, marginal spines; $C$, anal plate. From California material.

\section{Genus PULVINARIA Targ. \\ Pulvinaria ehrhorni King.}

Originally described from this area, from alder and willow. It is apparently rather rare, as I have obtained but a single specimen in five years of collecting. Presumably native.

The single specimen available shows some indications of abnormality and is hardly suitable material upon which to base a re-description. I may note, however, that while the species in life resembles $P$. vitis it is evidently distinct, as the marginal spines are filiform. In this respect it somewhat resembles $P$. rhois, differing however, from the latter in having the derm of the dorsum heavily chitinized instead of membranous. In certain respects it appears to resemble $P$. amygdali Ckll.

\section{Pulvinaria rhois Ehrh.}

Fig. 15 .

Described from this area. As far as known it occurs only on the "poison oak," Rhus diversiloba. I have seen specimens taken from this host at Walnut Creek, Contra Costa County, California. The species is 
very sporadic in its occurrence. The poison oak is one of our most abundant shrubs, yet I have met with the scale but twice, each time on isolated bushes and here in abundance. It is presumably native.

In all of the specimens examined the derm of the fully mature female is entirely membranous. The marginal spines (Fig. 15B) are slender

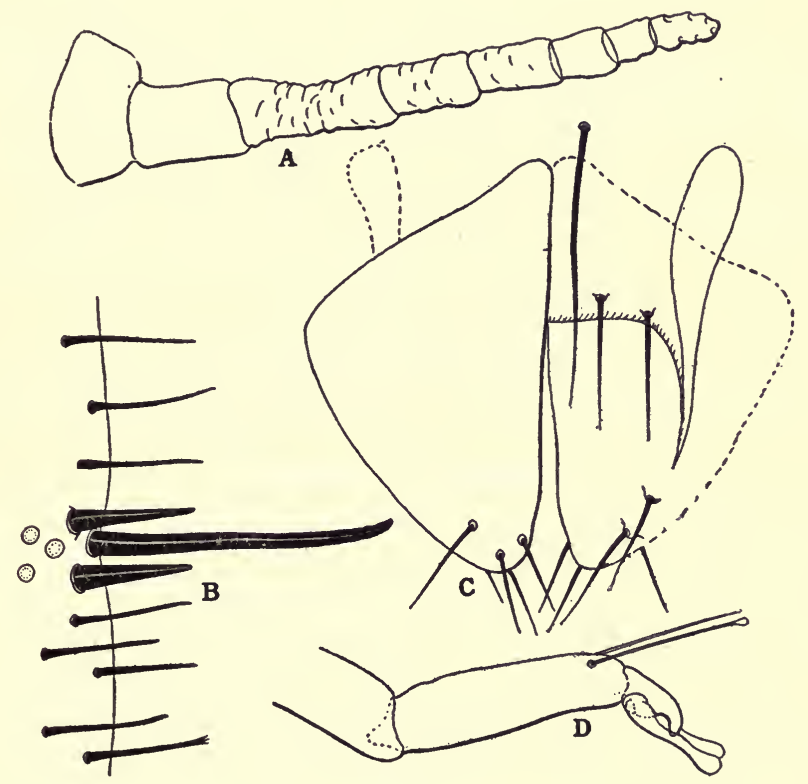

Fig. 15.-Pulvinaria rhois Ehrh.: $A$, antenna; $B$, marginal spines in the region of a stigmatic depression; $C$, anal plates, dorsal aspect left, ventral aspect right; $D$, tarsus and portion of tibia. From specimen from topotype material.

and quite long and are arranged in an irregularly single or double series. The stigmatic spines are large and conspicuous, the median spine being nearly three times as long as the others. Anal plates (Fig. $15 \mathrm{C}$ ) quite large and broad, each with three or four apical setæ on the dorsal side and two subapical setæ on the ventral side. Antennæ (Fig. 15A) normally 8-segmented. Legs rather stout, the claw (Fig. 15D) with very broad digitules. 


\section{Pulvinaria vitis (Linnæus).}

I have once taken this species from maples on the Stanford campus. It is probably more or less distributed throughout this area, but is certainly not abundant.

\section{Genus SAISSETIA Deplanches. ${ }^{3}$ \\ Saissetia oleæ (Bern.).}

Abundant upon a wide range of hosts. Among the wild plants that it especially favors are mistletoe and Baccharis pilularis. It has also been taken from Grindelia cuneifolia, Solanum sp. and Ceanothus sp.

\section{Saissetia nigra (Nietn.).}

This has been taken on Euonymus sp. on the Stanford campus.

\section{Genus COCCUS Linn.}

\section{Coccus hesperidum Linn.} hosts.

A very common species on a wide range of wild and cultivated Coccus citricola Campbell.

Said to occur at San Francisco. I have not seen specimens.

\section{Genus LECANIUM Burm.}

\section{Lecanium corni (Bouché).}

What appears to be entirely typical $L$. corni is abundant here on mulberry, apricot, prune, and other cultivated hosts. What is supposed to be this species has been taken from a long series of wild hosts, in cluding Alnus rhombifolia, Adenostoma fasciculatum, Arbutus menziesii, Ceanothus sp., Acer macrophyllum and Heteromeles arbutifolia. From the two last named hosts it has been described as new under the names of $L$. crawii Ehrh. and L. adenostomce Kuwana.

There is a very considerable diversity in appearance among specimens from these various hosts, ranging from a large, pruinose form on elm to a very small and shiny form on Arbutus, but there appear to be no structural differences. Whether all these forms belong to a single species can only be determined by extensive transference experiments.

${ }^{3}$ There is no evidence that $S$. hemisphaerica occurs out of doors in this area, although I have seen some of the small and shiny forms of Lecanium corni identified as this species. 


\section{Lecanium cerasorum Ckll.}

1915. Lecanium cerasorum Ckll.; Essig, "Injurious and Beneficial Insects of California," ed. 2, p. 145, fig. 124.

This is an introducd species that is now established in the vicinity of San Jose, where it occurs on fruit trees.

Structurally this appears to be inseparable from L. excrescens n. sp., which is described below, but the two differ greatly in appearance. As maturity approaches $L$. excrescens becomes covered with a thick coating of loose, white secretion, while $L$. cerasorum remains naked throughout. It is a very conspicuous object, the dorsum being marked with a series of regularly arranged white spots (well shown in the figure given by Essig), from which it has derived the popular name "calico scale."

There is nothing in the original description of this species that will permit its identification, and there is a possibility that the species here recorded as cerasorum is incorrectly determined.

\section{Lecanium pruinosum (Coq.).}

What is supposed to be this species is rather common on walnut.

\section{Lecanium pubescens Ehrh.}

Under this name there has been described from this region a form which occurs quite commonly on Quercus agrifolia and on Aesculus californicus. It differs from typical $L$. corni only in its somewhat larger size, the presence of rather evident, transverse dark bands in life and a slight amount of loose secretion (the "very soft hair" of the original description). Structurally it does not differ from L. corni.

\section{Lecanium excrescens n. sp.}

Fig. 16.

Type host and locality. From cultivated English walnut, Palo Alto, Calif. It occurs in this vicinity on almond and maple also.

Habit. A very large species, attaining a height of $8-10 \mathrm{~mm}$. and a diameter of $10 \mathrm{~mm}$. in the largest examples. In form the fully developed scales are very high convex (Fig. 16A), with the margin nearly perpendicular to the base, which is nearly circular in outline. During the last instar the scale becomes entirely covered with a thick coating of rather fluffy, white secretionary matter which disappears in weathered individuals, the latter being very dark brown and slightly shiny.

In the second and early third stages the dorsum is entirely destitute of secretion except for a number of symmetrically and characteristically 
arranged lumps of pure white wax. (No examples of these stages are available for figuring.) Beneath these lumps the derm, elsewhere dark brown, is distinctly yellow.

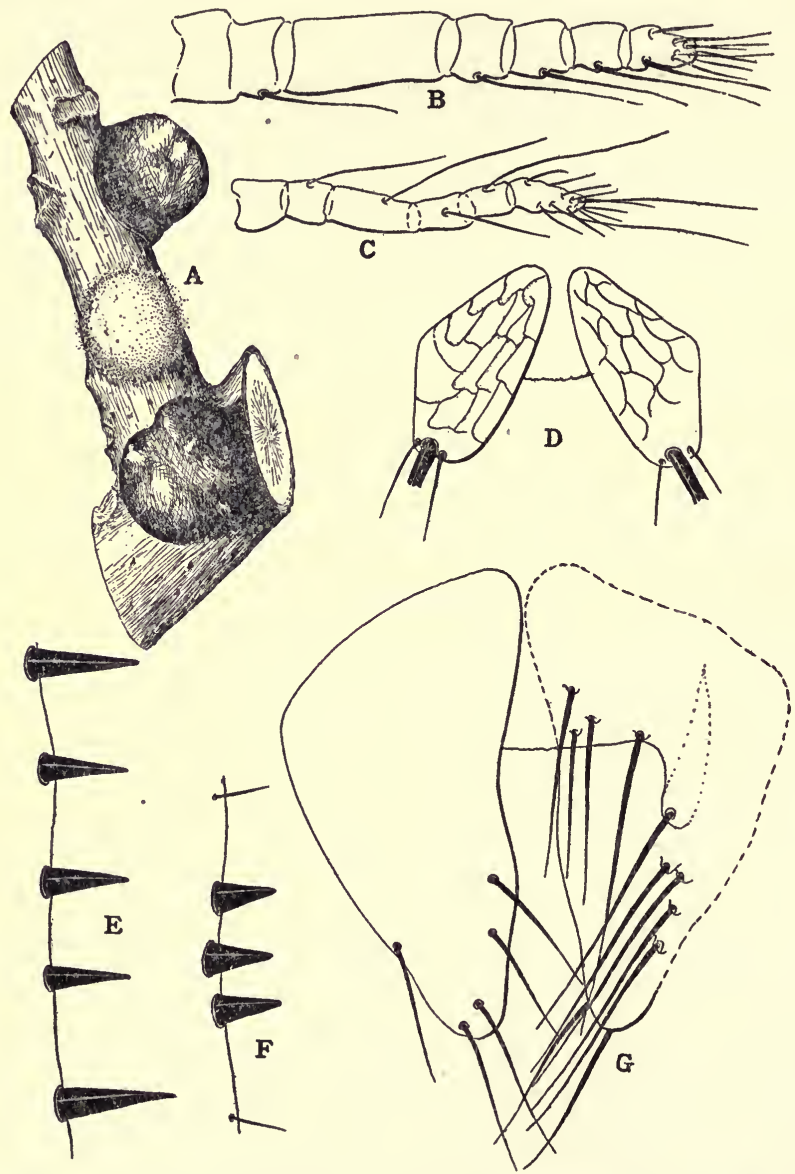

Fig. 16.-Lecanium excrescens n. sp.: $A$, habit; $B$, antenna of adult female; $C$, antenna of first stage; $D$, anal plates of first stage; $E$, marginal spines of adult at region of a stigmatic depression; $F$, marginal spines of first stage at region of stigmatic depression; $G$, anal plates of adult, dorsal aspect left, ventral aspect right. 
Morphological characteristics. Marginal spines (Fig. 16E) arranged in a very definite single row, quite large and sharply conical, their distance apart depending upon the size of the insect. In specimens taken before the beginning of the period of rapid growth the spines are separated by intervals scarcely greater than the width of the base of a single spine. Stigmatic spines scarcely or not at all differentiated, the stigmatic clefts practically obsolete. Anal plates (Fig. 16G) very large, rather long and narrow, with a varying number of setæ near the apex, with as many as five subapical setæ on the ventral side and with as many as ten fringe setæ. Antennæ (Fig. 16B) rather short, normally 7 -segmented, the third segment conspicuously longer than any of the others. Legs small, not stout, the claw with two slender digitules. Pores of the dorsum abundant, small, not arranged in any definite manner.

Second stage not available for description.

First stage with three small stigmatic spines (Fig. 16F) in each stigmatic depression and with marginal spines represented by a few slender setæ. Anal plates (Fig. 16D) of the form usual in the genus, but with their dorsum presenting a tessellated appearànce. Antennæ (Fig. 16C) 6-segmented.

Notes: The holotype is a mount of a specimen in the last instar but not fully grown and with the derm still membranous.

This species is one of a group to which belong $L$. caryae (Fitch) of the eastern states and another species (certainly introduced) which occurs in California and passes as L. cerasorum Ckll. From the former it differs in its much more convex form and in having more hairs on the anal lobes. From the latter it does not differ at all structurally, but this species remains destitute of secretion at maturity and in life is so conspicuously marked with large white spots that it has been called the "calico scale." Judging from the description of that species, $L$. glandi Kuwana is very similar in appearance but differs in having the marginal spines slender.

\section{Genus PHYSOKERMES Targ.}

The existing descriptions of this genus make no mention of its most important character and in certain respects require modification. I present the following diagnosis.

Coccidæ referable to the subfamily Coccinæ, characterized, as are the other members of this subfamily, by the presence of a pair of triangular, supra-anal plates in the first and second instars, but differing from all other members of this group by the absence of these plates in the last instar, the plates being replaced at the second molt by a single median lobe. Marginal spines lacking in the adult, the stigmatic depressions not indicated. Antennæ and legs either present or absent in the adult female. 
Body form globular, the venter being deeply intussuscepted and forming a marsupium for the retention of the eggs. Infesting, as far as known, only coniferous hosts.

Notes: The loss of the anal plates at the final ecdysis appears to have been overlooked by earlier writers, only a single author ${ }^{4}$ having noted the fact and this without comment. The absence of these plates has been established only in $P$. piceae (the type of the genus) and $P$. insignicola, but it may safely be assumed that the remaining species of the genus are similar.

\section{Physokermes insignicola (Craw).}

Fig. 17.

Originally described from this area where it is something of a pest on the Monterey Pine (Pinus radiata).

This species has been the subject of an extensive paper by Moulton in which, unfortunately, its morphology has been but inadequately dealt with. I append the following notes.

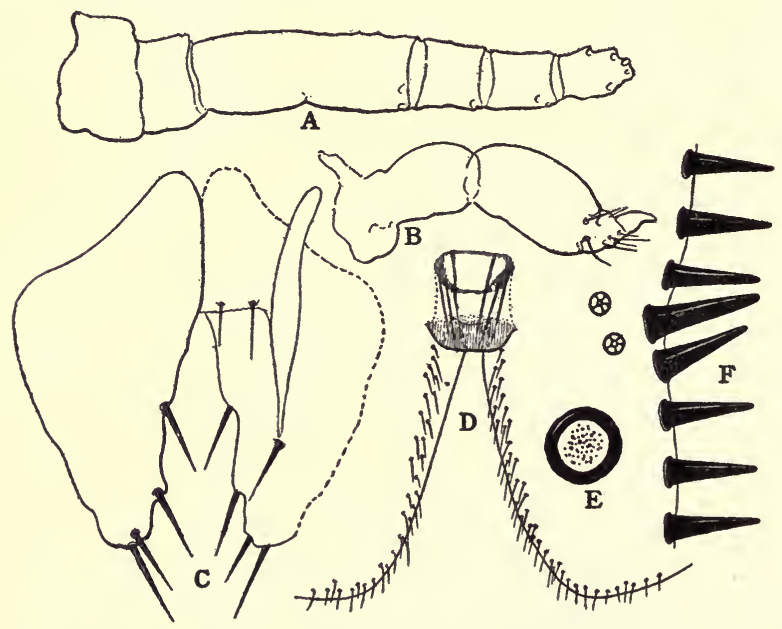

Fig. 17.-Physokermes insignicola (Craw) : $A$, antenna of adult female; $B$, leg of adult female; $C$, anal plates of second stage; $D$, anal region of adult; $E$, dorsal pore; $F$, marginal spines from region of stigmatic depression of second stage female.

Adult female, taken before the chitinization of the derm has set in. Legs and antennæ present, the former (Fig. 17B) very short and stout,

${ }^{4}$ Fenton, F. A., Can. Ent., 49:320. (1917) 
more or less misshapen and with the tarsus much reduced, the latter (Fig. $17 A$ ) well formed and large, 6-segmented, with the third segment very long. Stigmatic depressions not indicated, the stigmatic spines lacking. Marginal spines lacking except along the margins of the anal cleft (Fig. $17 D)$, where there are numerous slender setæ. Anal ring practically simple, bearing six short setæ. Dorsum beset with small, circular pores with a chitinized rim (Fig. $17 E$ ), which are especially numerous over the posterior half. In fully mature individuals the derm becomes extremely heavily chitinized, and it is practically impossible to obtain preparations in which these various structures can be seen.

Second stage with the antennæ practically as in the adult but slightly more slender. Legs well formed, large and slender. Marginal spines (Fig. 17F) quite large, slender, conical, set in a sharply defined single row, the spines being separated from each other by a distance of scarcely more than the width of their bases. Stigmatic depressions scarcely noticeable, the stigmatic spines but little or not at all larger than the other marginal spines. Anal plates (Fig. 17C) rather slender, each with three apical spines and a single spine on the mesal margin and a single subapical spine on the ventral side. There are four very small fringe setæ.

First stage not seen.

\section{Physokermes taxifoliæ Coleman.}

Originally described from this area, where it occurs rather sparingly on the Douglas spruce, Pseudotsuga taxifolia. I have been unable to obtain suitable specimens for microscopic examination.

\section{Genus TOUMEYELLA Ck11.}

\section{Toumeyella pinicola n. sp.}

Fig. 18.

Type host and locality. From Pinus radiata on the grounds of the Spring Valley Water Company at Aqua, San Mateo County, Calif.

Habit. Occurring on the small twigs at the bases of the needles. Entirely destitute of secretion; dried specimens much wrinkled, more or less irregular in form because of crowding, somewhat straw colored except for a small brown area about the anal plates. Length about $3 \mathrm{~mm}$.

Morphological characteristics. Derm entirely membranous except for a heavily chitinized, circular area about the anal plates. Marginal spines very few, small and slender. Stigmatic spines (Fig. 18E) short and stout, somewhat spindle shaped, the middle spine not longer than the others. Stigmatic depressions shallow, marked by a broad zone of circular pores.which extends in to the corresponding spiracle. Anal plates (Fig. 18B) large, the cephalic margin distinctly longer than the caudal 
margin. Each plate with several apical and subapical setæ on the dorsal side and two or three subapical setæ on the ventral side. There is a single very long fringe seta at each side and there are numerous hypopy-

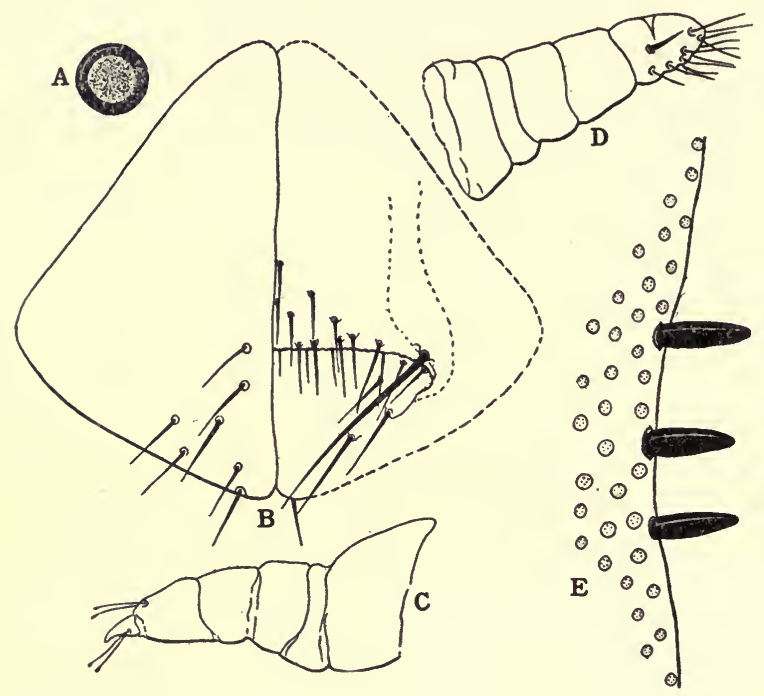

Fig. 18.-Toumeyella pinicola n. sp.: $A$, dorsal pore; $B$, anal plates, dorsal aspect left, ventral aspect right; $C$, leg of adult; $D$, antenna of adult; $E$, stigmatic spines of adult.

gial setæ. Anterior to the anal plates are numbers of the conspicuous pores (Fig. 18A), which are rather characteristic of the genus, the majority of these pores lying within the chitinized area. Legs (Fig. 18C) and antennæ (Fig. 18D) small and stout, the latter obscurely 6-segmented.

Immature stages not observed.

Notes: I have at hand specimens of a Toumeyella from pine in Florida which probably represent $T$. parvicorne (Ckll.) and which differ from the new species in having the cephalic and caudal margins of the anal plates equal and the median stigmatic spine longer than the others. As $T$. pini King is probably a synonym of $T$. parvicorne the new species may not be referred to pini.

It is almost certain that this is an introduced species as it has never been found upon the Monterey Pine in its native habitat. 


\section{Genus CHIONASPIS Sign.}

This genus has been greatly restricted by Cooley, and in all probability justly so, but no provision has been made for the species that have been excluded from it. Therefore, while accepting this restriction I am still retaining in the genus such forms as $C$. spartince Comst. and $C$. quercus Comst., not caring at present to undertake the responsibility of defining new genera for them, however different they may be from the type of Chionaspis.

\section{Chionaspis quercus Comst.}

Fig. 19.

Common on the various species of Quercus and also on the tan oak, Pasania densiflora.

Of this species there are none but the rather crude figures accompanying the original description and a later note by Essig. I present a

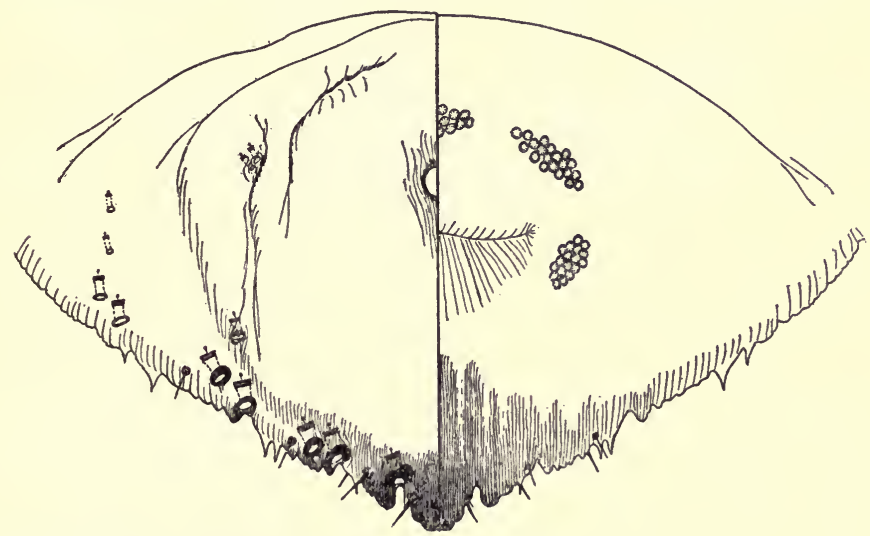

Fig. 19.-Chionaspis quercus Comst.: pygidium of specimen from Quercus agrifolia.

new figure. The original description is quite accurate, but I may note that the dorsum of the abdomen is almost destitute of ducts and that there are a few ducts and gland spines at the margins of each abdominal segment.

\section{Chionaspis pinifoliæ (Fitch).}

Abundant upon the numerous species of pines grown here as ornamentals. Also on Pseudotsuga taxifolia and Torreya californica. It is probably to be regarded as native. 


\section{Chionaspis spartinæ Comst.}

Fig. 20 .

Found, in this area, only on a salt marsh grass, Spartina stricta, about San Francisco Bay.

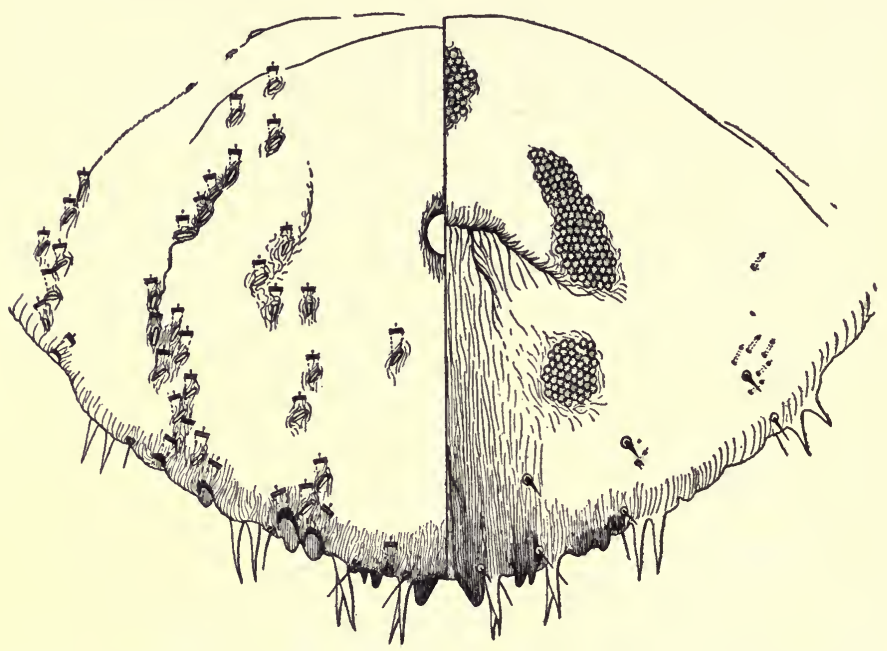

Fig. 20.-Chionaspis spartince Comst.: pygidium of specimen from California material.

I present a new figure of the pygidium. The dorsum of the abdomen is practically destitute of ducts, but there are numerous small ducts at the lateral margins and there is a more or less well-defined row of large ducts anterior to those shown in the figure. There are no gland spines anterior to the pygidium.

\section{Genus DIASPIS Costa.}

With this genus I am uniting Epidiaspis Ckll. In characterizing Epidiaspis originally as a subgenus of Diaspis, Cockerell has stated that $D$. piricola (the type of the former genus) "has the club-shaped glands at the bases of the lobes, as in Diaspidiotus, and I think that it is related thereto rather than to Diaspis." As a matter of fact, these "club-shaped glands," which are not glands at all, but merely chitinous thickenings, are morphologically very different from the thickenings seen in Aspidiotus. In the latter genus these thickenings bound the margins of the poriferous furrows, while in $D$. piricola they are the much enlarged thickenings that 
are always present in some degree of development about the bases of the marginal spines. In all other respects $D$. piricola is a perfectly typical species of Diaspis. As far as the unusual development of these thickenings is concerned the species is connected with typical Diaspis by such a form as $D$. montana Ckll., in which there is an obvious tendency in the same direction.

Certain other species that have been ascribed to Epidiaspis should probably likewise be referred to Diaspis.

Diaspis carueli Targ.

Very abundant on Libocedrus decurrens, Thuya sp. and various species of Cupressus on the Stanford campus and doubtless elsewhere. An introduced species.

\section{Diaspis echinocacti (Bouché).}

On various species of cacti on the Stanford University campus. An introduced species.

\section{Diaspis manzanitæ (Whitney).}

Fig. 21.

I have found this species in but a single restricted locality, near Summit Rock, above Saratoga, at an altitude of approximately 3000 feet, where it occurs on the leaves of some species of Arctostaphylos.

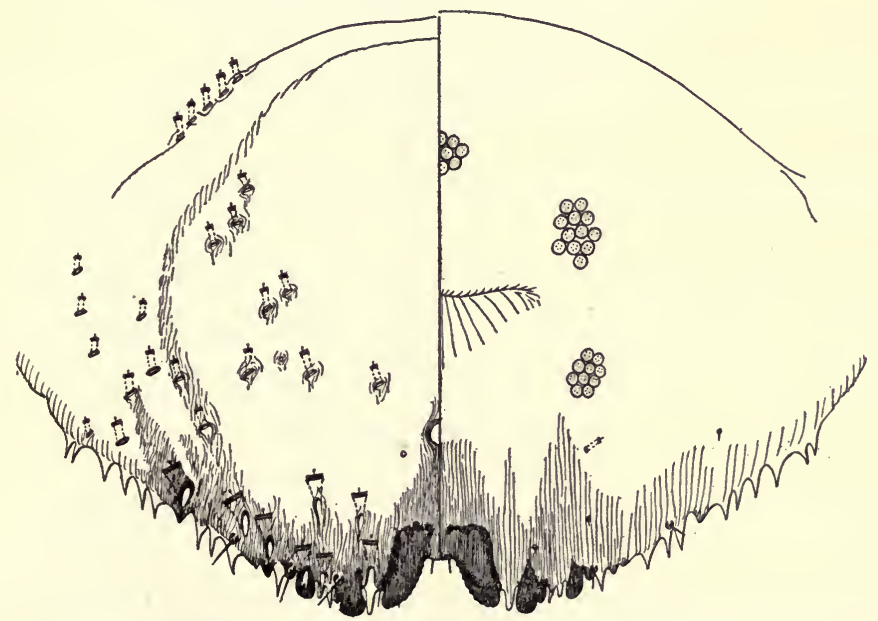

Fig. 21.-Diaspis manzanite (Whitney) : pygidium of specimen from Santa Cruz Peninsula. 
This was originally described as an Aulacaspis, but by reason of the scattered dorsal pores of the pygidium it is distinctly a Diaspis. The accompanying figure will supplement the original description.

\section{Diaspis piricola (Del Guer.).}

Fig. 22.

Common on pear and prune. The only native host that it is known to attack is the Christmas berry, Heteromeles arbutifolia, upon which it becomes extremely abundant.

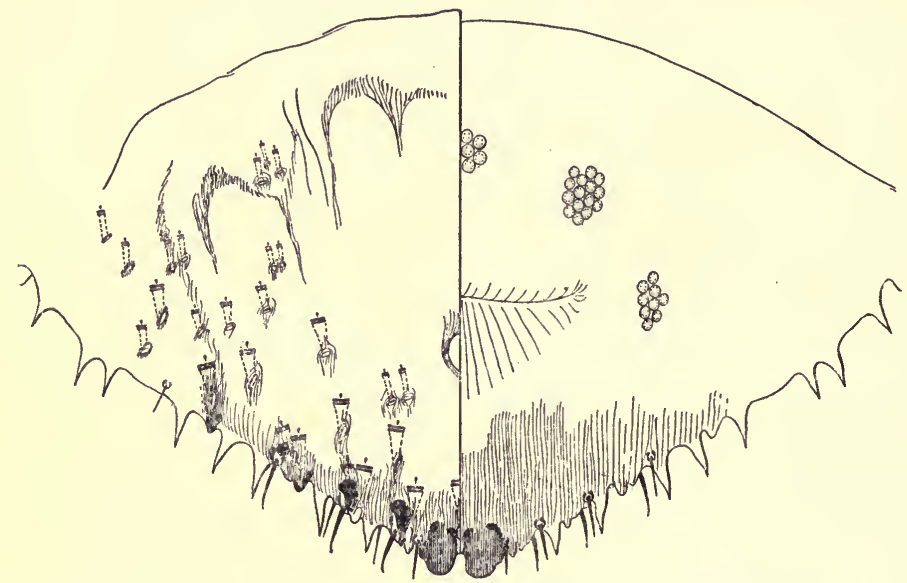

Fig. 22.-Diaspis piricola (Del Guer.): pygidium of specimen from prune on the Santa Cruz Peninsula.

I have pointed out in the discussion of the gemus Diaspis the grounds for rejecting Epidiaspis and restoring this species to the former genus. The only figures of $D$. piricola that I have seen are inadequate or even quite misleading, and I present a new figure of the pygidium.

\section{Genus AULACASPIS Ckll. \\ Aulacaspis rosæ (Bouché).}

Rather common on roses, cultivated blackberries and raspberries.

Genus DINASPIS Leonardi.

I have not been able to see the original description of this genus and am referring one species, Leucaspis kelloggi Coleman, to it upon the suggestion of Mr. E. E. Green. 


\section{Dinaspis kelloggi (Coleman).}

Fig. 23.

A native species, originally described from this area, where it occurs rather commonly on the Douglas Spruce, Pseudotsuga taxifolia and occasionally on pine.

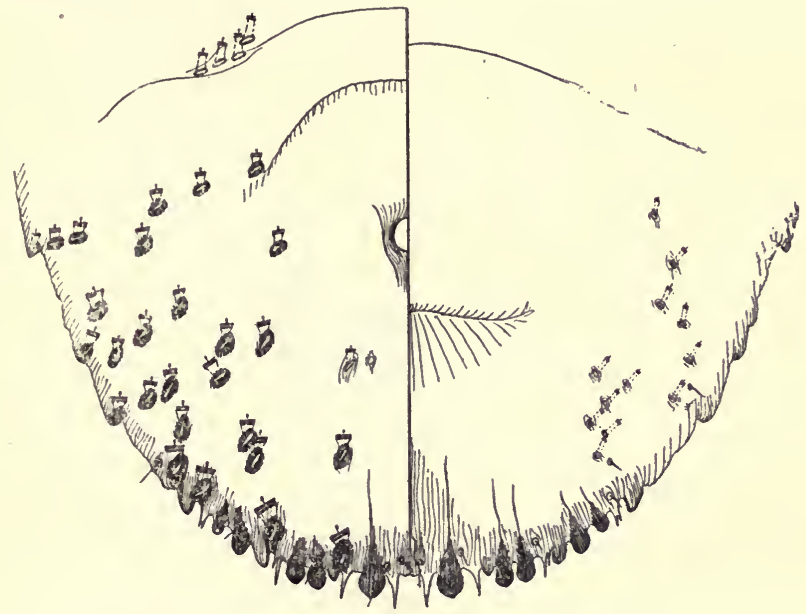

Fig. 23.-Dinaspis kelloggi (Coleman) : pygidium of specimen from Pseudotsuga taxifolia on the Santa Cruz Peninsula.

The original description of the species is quite accurate, but the figure of the pygidium leaves much to be desired and I present a new figure. The species is certainly not a Leucaspis.

\section{Genus LEPIDOSAPHES Shimer. \\ Lepidosaphes newsteadi (Sulc).}

Recorded by Coleman from Sciadopitys, near Stanford University.

Lepidosaphes ulmi (Linn.).

A common species on willow and apple. I have also taken it from passion flower and from a native host, Xylothermia (or Pickeringia) montana.

${ }^{5}$ It is probable that $L$. ceanothi Ferris occurs in this area, as scales almost certainly of this species have been seen upon Ceanothus. However, no specimens are available and the record can not be definitely established. 


\section{Genus ASPIDIOTUS Bouché.}

\section{Aspidiotus aesculi Johns.}

Fig. 24.

Originally described from this locality, where it is frequently abundant on Aesculus californicus. It is usually associated with a pitting and roughening of the bark, for which it is perhaps responsible.

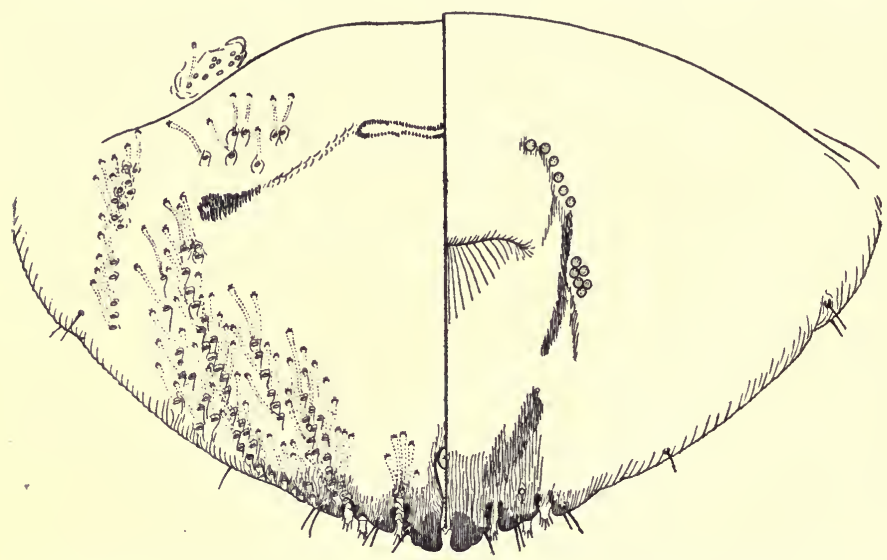

Fig. 24.-Aspidiotus asculi Johns.: pygidium of topotype specimen.

I have at hand specimens from box elder (Acer negundo) and poplar at Salt Lake City, Utah, and from poplar near Lone Pine, Inyo County, Calif., which I refer to this species. As all these specimens agree also with the description and figure of $A$. popularum Marlatt, which was described from poplar in New Mexico, I place the latter species as a synonym of esculi.

\section{Aspidiotus arctostaphyli Ckll. and Rob.}

Fig. 25.

What appears to be this species has been taken from Arctostaphylos sp. near Los Gatos. The specimens are immature, and the determination is not entirely certain, but the record may be accepted without much doubt.

The accompanying figure of this species is from a specimen from Arctostaphylos sp., near Redding, Calif. Attention should be called to 
the presence of numerous ducts near the margins of the last abdominal segment anterior to the pygidium. The presence of these ducts will serve to separate this from the very similar $A$. densiflore Bremner.

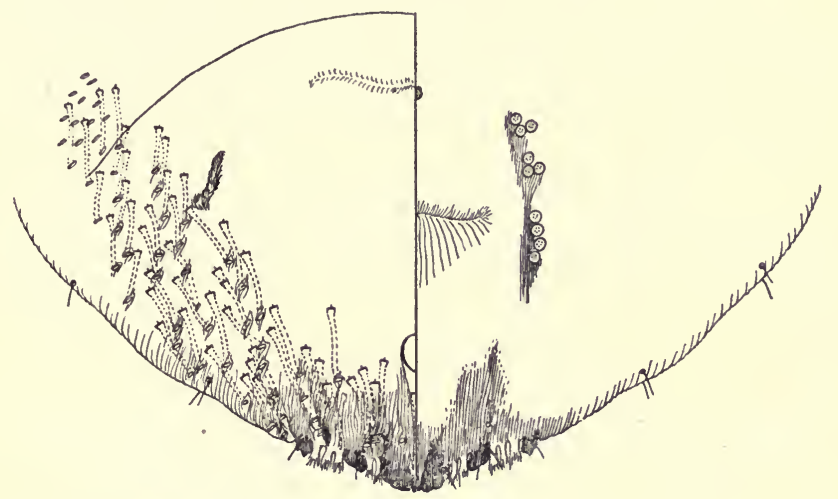

Fig. 25.-Aspidiotus arctostaphyli Ckll. and Rob.: pygidium of specimen from near Redding, Calif.

\section{Aspidiotus coniferarum Ckll.}

Fig. 26.

Abundant on the bark of Libocedrus decurrens, on the campus of Stanford University. It is probably introduced. It has previously been

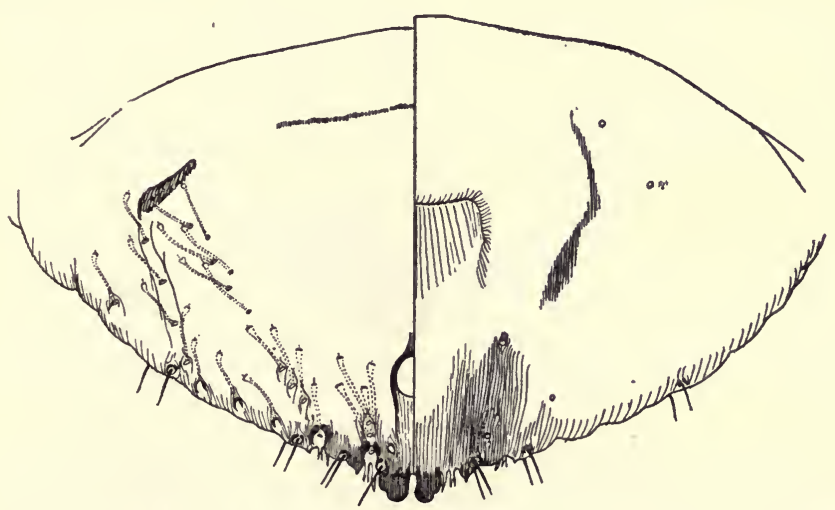

Fig. 26.-Aspidiotus coniferarum Ckll.: pygidium of specimen from Libocedrus decurrens on the Santa Cruz Peninsula. 
recorded only from pine in New Mexico, but I have specimens from Cupressus guadelupensis at Riverside and Libocedrus decurrens, Mt. Shasta and near Yosemite Valley, Calif.

Through the kindness of Professor Cockerell I have been enabled to examine a specimen from the type material of this species. The only difference observable between this specimen and those from Libocedrus and Cupressus is that the median lobes of the New Mexico specimen are a trifle broader.

The following notes may be added to the original description.

Derm entirely membranous, except for the pygidium. Tubular ducts confined to the pygidium, these small, slender, varying somewhat in number but always few, their arrangement as indicated in the accompanying figure.

\section{Aspidiotus densifloræ Bremner.}

Fig. 27.

Occurring quite commonly on the leaves of the tan oak (Pasania densiflora) and occasionally on the leaves of Quercus chrysolepis.

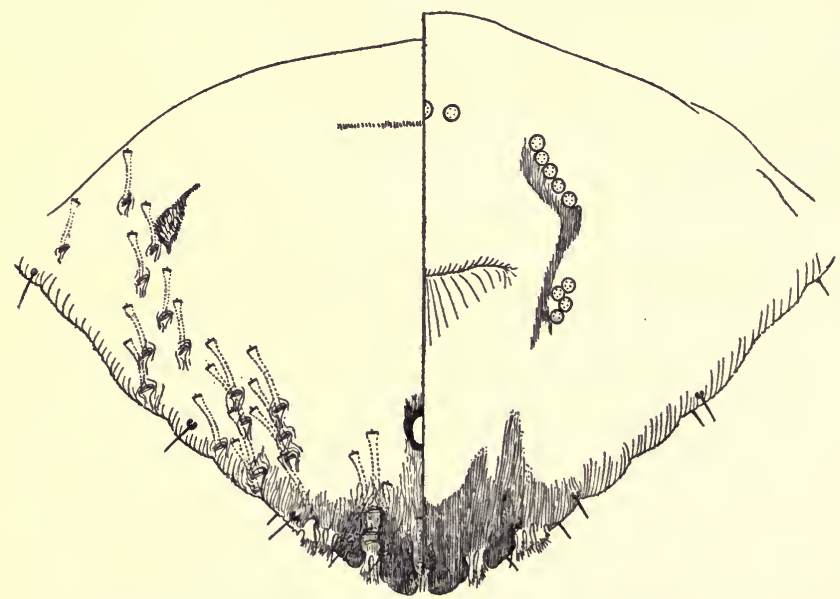

Fig. 27.-Aspidiotus densiflore Bremner: pygidium of specimen from Pasania densiflora on the Santa Cruz Peninsula.

I present a new figure of the pygidium. This species very closely resembles $A$. arctostaphyli but may be distinguished by the absence of a cluster of ducts at each lateral margin on the first abdominal segment anterior to the pygidium. 


\section{Aspidiotus ehrhorni Coleman.}

Fig. 28.

Within this area this species has been taken only from the bark of Pseudotsuga taxifolia.

The original description is in error in the statement that there are three pairs of "incisions" on the pygidium. There are but the usual two

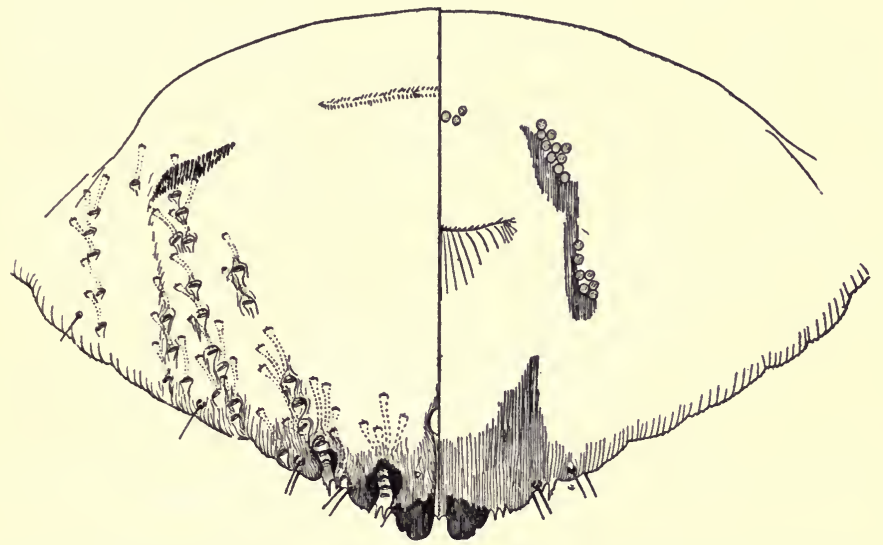

Fig. 28.-Aspidiotus ehrhorni Coleman: pygidium of specimen from Pseudotsuga taxifolia on the Santa Cruz Peninsula.

pairs. I may note further that the derm is membranous, except for the pygidium, and that the tubular ducts are confined to the pygidium, except for one or two at the lateral margins on some of the abdominal segments. The figure accompanying the original description is quite inadequate and I present a new figure.

\section{Aspidiotus hederæ (Vall.).}

Sharing with $A$. rapax the distinction of being one of the two most common scales in this area. It occurs on an extremely wide range of wild and cultivated hosts, among the former being Arbutus menziesii, Alnus rhombifolia, several species of Arctostaphylos, Umbellularia californica, Ceanothus sp. and Sequoia sempervirens.

\section{Aspidiotus osborni Ck11.}

Fig. 29.

Quite common on the bark of Quercus agrifolia, but rarely seen because of the close resemblance of the scales to the bark of the host.

Aspidiotus yulupe Bremner is a synonym of this. I may note that the derm of the abdomen is membranous, except for the pygidium, and 
the dorsal ducts are confined to the pygidium except for a very few along the lateral margins of the abdominal segments.

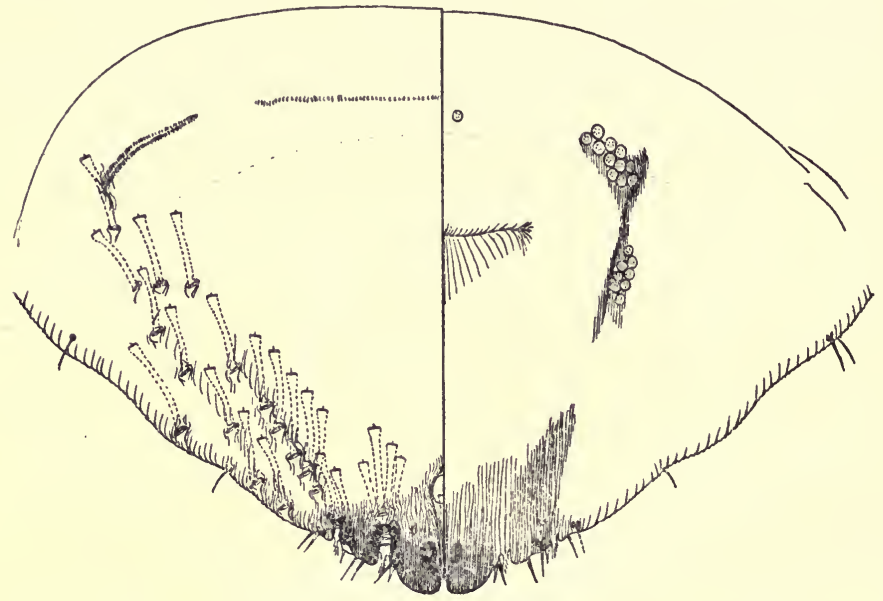

Fig. 29.-Aspidiotus osborni Ck11. : pygidium of specimen from Quercus agrifolia on the Santa Cruz Peninsula.

This species is very close to $A$. ehrhorni, differing chiefly in having the lateral margin of the median lobes more rounded and in not having a series of ducts in the extreme lateral angles of the pygidium.

\section{Aspidiotus perniciosus Comst.}

Although this species was first described from this area it is not now a serious pest. It is quite frequently met with in old orchards, but has not been found on any native host.

\section{Aspidiotus pini Comst.}

Figs. 30 and 31 .

1881. Aspidiotus ? pini Comstock, Rept. U. S. Dept. Agric., 1880, p. 306.

1894. Aspidiotus abietis (Schr.); Ck11., Can. Ent., 26:190. (Part.)

1903. Aspidiotus abietis (Schr.) ; Fernald, Cat. Coccidæ, p. 251. (Part.)

1903. Aspidiotus californicus Coleman, Jn. N. Y. Ent. Soc., $11: 64$.

1903. Aspidiotus abietes Comst.; Coleman, Ibid., p. 74. (Misidentification.)

Abundant on various species of pines and on Pseudotsuga taxifolia. Probably native.

To the original description of Comstock I have only to add the following notes. 
Fully mature female (Fig. 30) more or less circular in form, with the derm very heavily chitinized except for the pygidium and one or two abdominal segments anterior to the pygidium. The pygidium is retracted into the ventral side of the abdomen. Specimens taken at this stage are difficult to study morphologically owing to the heavy chitinization of the derm.

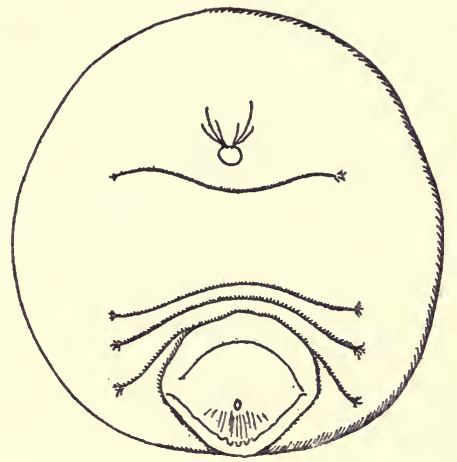

Fig. 30.-Aspidiotus pini Comst.: ventral aspect of adult female from specimen from pine, Ithaca, N. Y.

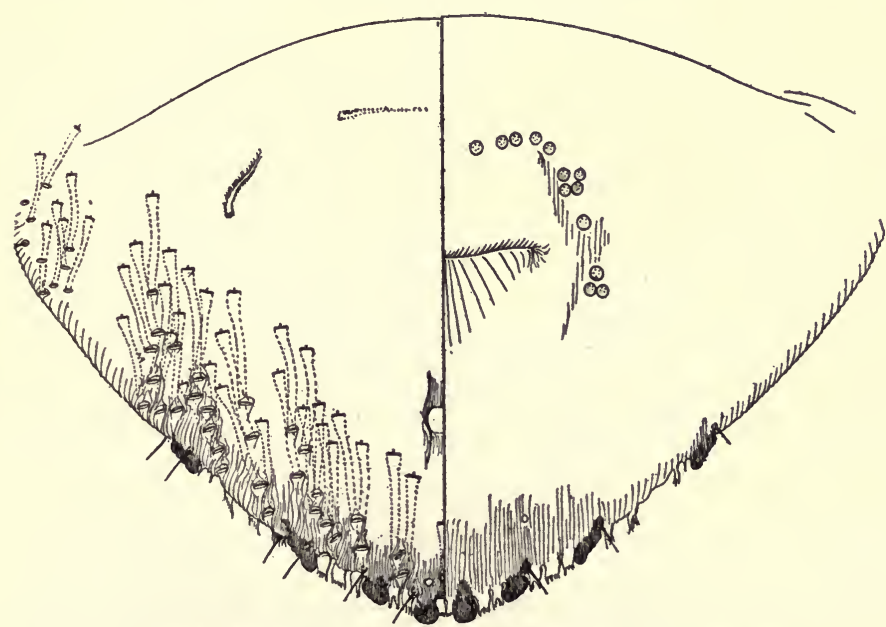

Fig. 31.-Aspidiotus pini Comst.: pygidium of specimen from pine, Ithaca, N. Y. 
In the early adult female the derm is membranous throughout, except for the pygidium. At this stage there may be seen a cluster of numerous ducts at the lateral margin of each of the abdominal segments anterior to the pygidium. The dorsal ducts are very numerous and are arranged as shown in Fig. 31.

Notes: I am here restoring, at least temporarily, the name Aspidiotus pini Comstock. This has been placed by Cockerell as a synonym of A. abietis (Schr.) but material in my hands, representing both species, indicates that they are possibly distinct. Aspidiotus californicus Coleman is certainly a synonym of $A$. pini. I shall discuss these species at length in another paper dealing with the coniferinfesting species of this group occurring in North America.

\section{Aspidiotus rapax Comst.}

Like $A$. hederce, and frequently in company with it, this species occurs on a wide range of hosts. At times it is so abundant on the native shrubs of the genus Ceanothus as to be destructive.

\section{Aspidiotus shastæ Coleman.}

Fig. 32.

On Sequoia sempervirens, at times in great abundance, always on the leaves.

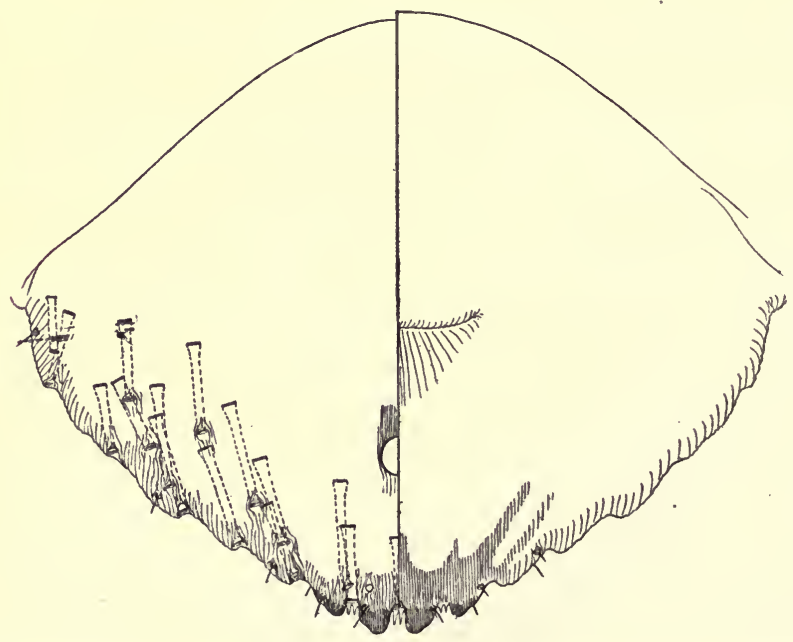

Fig. 32.-Aspidiotus shaste Coleman : pygidium of specimen from Sequoia sempervirens on the Santa Cruz Peninsula. 
This is the species described by Coleman as A. coniferarum var. shaste and more recently by Marlatt as Aonidia juniperi. It is certainly congeneric with and perhaps the same as Aspidiotus (=Cryptaspidiotus) mediterraneus Lindinger, which occurs on Juniperus in the Mediterranean region and of which I have specimens. The genus Cryptaspidiotus must eventually be recognized, but it has not been adequately characterized, and in the present state of our knowledge of this group to limit it is difficult. I therefore retain the species for the present in Aspidiotus.

\section{Genus CHRYSOMPHALUS Ashmead.}

Chrysomphalus rossi (Maskell).

Fig. 33.

On Araucaria bidwilli, on the campus of Stanford University. An introduced species. Specimens from this locality agree entirely with material from Australia determined by Froggatt as this species.

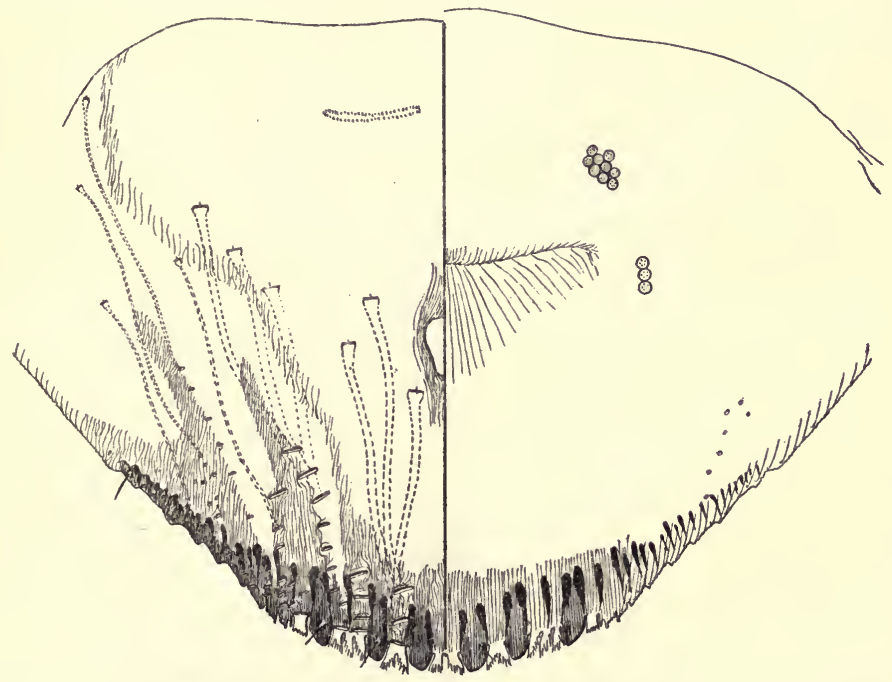

Fig. 33.-Chrysomphalus rossi (Maskell) : pygidium of specimen from Araucaria on the Santa Cruz Peninsula.

The figure of the pygidium given by Green in the Coccidæ of Ceylon is hardly as detailed as is desirable, and I present a new figure. The mixture of large and small ducts on the dorsum is a characteristic feature of the species. 


\section{Genus TARGIONIA Sign.}

The type of this genus is a somewhat Chrysomphaloid form with which probably few of the North American species now referred to this genus are strictly congeneric. I consider that the one species coming within the scope of this paper, $T$. dearnessi Ckll. and Par., should probably be referred elsewhere and that a new genus will eventually be necessary for this and certain other closely allied species. I would especially call attention to the nature of the ducts in all these species.

\section{Targionia (?) dearnessi Ckll.}

Fig. 34 .

From Grindelia cuneifolia in the salt marshes about San Francisco Bay and from Eriophyllum confertiflorum in Stevens Creek Canyon. This species is also abundant on Corethrogyne sp. at Cypress Point near Pacific Grove.

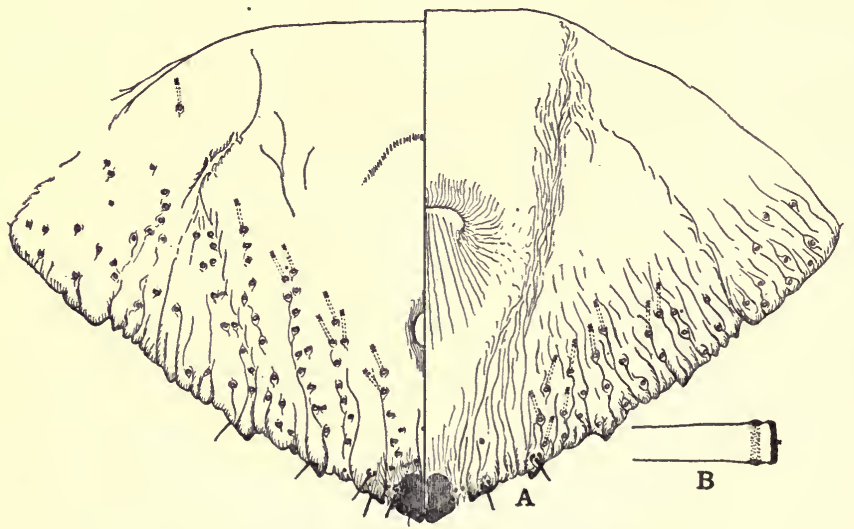

Fig. 34.-Targionia (?) dearnessi Ck11.: $A$, pygidium; $B$, duct. From specimen from type material.

The accompanying figure will supplement the original description, and I may note that there are numerous ducts along the lateral margins of the abdomen. All the ducts are very small and short and appear to be of the type indicated in Fig. 34B. The determination of the species is based upon the examination of specimens from the type material. 


\section{Genus ODONASPIS Sign.}

Odonaspis graminis Bremner.

Fig. 35 .

Originally described from roots of grass on the Presidio Hills at San Francisco. I have taken the species from a perennial grass near Searsville Lake, San Mateo County.

I present a figure of the pygidium.

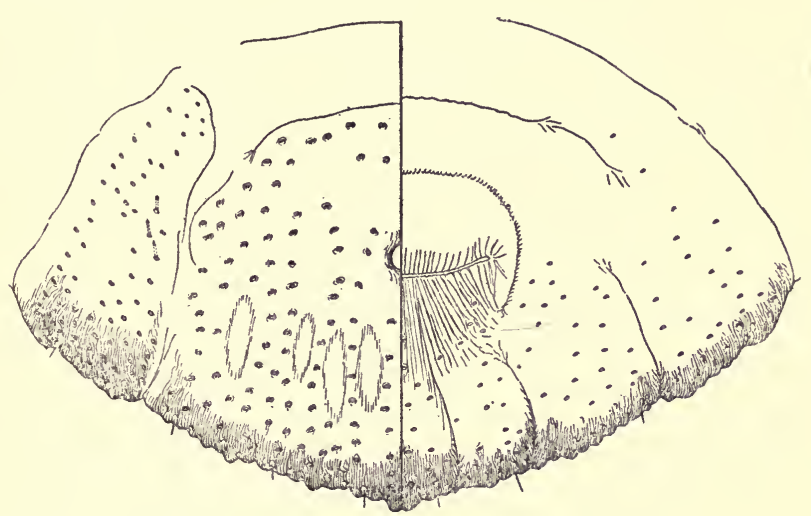

Fig. 35.-Odonaspis graminis Bremner: pygidium from specimen from near Stanford University. 








University of California

SOUTHERN REGIONAL LIBRARY FACILITY

305 De Neve Drive - Parking Lot 17 - Box 951388

LOS ANGELES, CALIFORNIA 90095-1388

Return this material to the library from which it was borrowed.

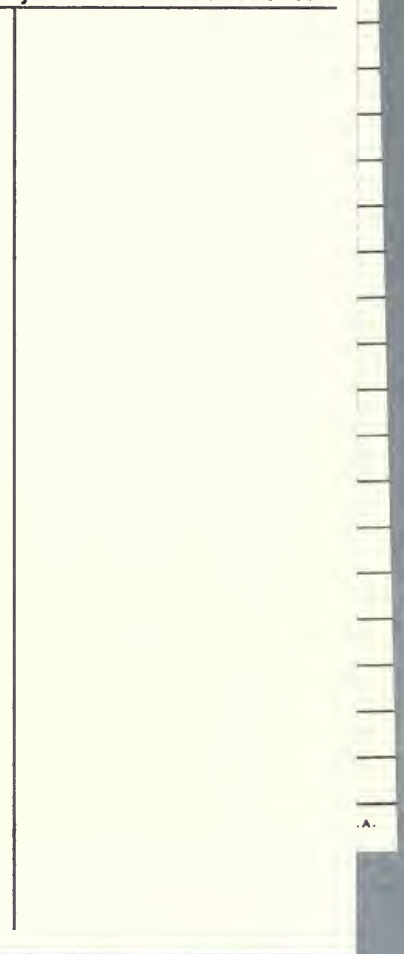


QL523

C7F 47

1920

Ferris, Gordon Floyd

Scale insects of the Santa.

Cruz Peninsula.

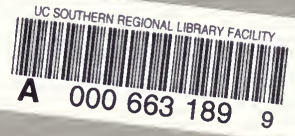

QL523

C7F47 Ferris, Gordon Floyd

1920

Scale insects of the Santa Cruz Peninsula.

BIO-AGRICULTURAĹ LIBRARY

UNIVERSITY OF CALIFORNIA

RIVERSIDE, CALIFORNIA 92502 
